Journal of Forensic Economics 20(3), 2007, pp. 271-314

(C) 2009 by the National Association of Forensic Economics

\title{
Assessing Economic Damages in Personal Injury and Wrongful Death Litigation: The State of Illinois
}

\author{
Gary R. Skoog and James E. Ciecka*
}

\section{Introduction ${ }^{1}$}

Forensic economics experts (FE) working with attorneys engaged in litigation, whether consulting, preparing a report, or testifying at deposition or trial, generally are expected to have some knowledge (1) of the state's statutory and case law regarding allowable damages and methods; and (2) that certain topics (e.g., taxes, collateral sources) should not be mentioned or considered at certain times since a mistrial could result. This situation creates a tension: forensic economics experts are economics experts and are not attorneys, but nonetheless must have a reasonable understanding of the relevant state law. In this vein, the Journal of Forensic Economics (JFE) continues to publish a series of articles on the ways such damages are calculated in different state jurisdictions, one state at a time. ${ }^{2}$ The state of South Dakota is included in this issue and this paper adds Illinois to the list.

Following the format of previous articles in this JFE series, Section II provides a listing of the controlling statutes, general case law, and court rules. Section III discusses the concept of earning capacity which appears throughout PI and WD case law in Illinois. Section IV discusses discounting to present value. Fringe benefits are discussed in Section V, while Section

*Gary R. Skoog, Legal Econometrics, Inc., Glenview, IL and DePaul University, Department of Economics, Chicago; James E. Ciecka, DePaul University, Department of Economics, Chicago. The authors wish to thank Judge David Cerda, Retired Illinois Appellate Court Justice; Timothy J. Lowrey of Lowrey \& Associates; and Michael Lubeck and James Newman of Cooney And Conway for graciously giving their time to read this paper while it was in manuscript form. Robert A. Male and James D. Rodgers, editors of the series on assessing economic damages in individual states, read two manuscript versions of the paper and provided detailed comments on both versions. Two anonymous referees also provided valuable suggestions to improve this paper. The comments of all of the above named individuals led to a greatly improved final product. We also wish to thank Nik Kohrt for shepardizing and organizing cases and Nancy Eldredge for manuscript editing. Of course, any errors are ours.

${ }^{1}$ These papers are part of a series being prepared on economic damages in personal injury and wrongful death cases by state. A description of this series appeared as Robert A. Male and James D. Rodgers, "Introduction," Journal of Forensic Economics, Vol. 15, No. 3, Fall, 2002, pp. 317-18. Prospective authors of a paper for the series should consult that introduction and contact Male and Rodgers for information about the sequence of steps in the development and submission process, and also about papers already being developed or reviewed.

${ }^{2}$ Papers treating Pennsylvania, Florida, Oregon (JFE 15(3)), Wyoming and Missouri (JFE 16(1)), Puerto Rico and West Virginia (JFE 16(3)), Mississippi and Georgia (JFE 17(1)), Ohio and Kentucky (JFE 17(2)), California and Idaho (JFE 17(3)), Kansas and Utah (JFE 18(2-3)), and North Carolina and Connecticut (JFE 19(1)), Tennessee and Alabama (19(3)), and Texas (20(1)) have appeared. The outline and common wording followed here is closest to our neighbor state of Missouri. 
VI discusses the treatment of income taxes. Household services are discussed in Section VII, and the personal consumption deduction is discussed in Section VIII. Section IX discusses medical expenses and life care plans, and Section X deals with hedonic damages. Section XI addresses various miscellaneous issues of interest to FE's. Section XII is a summary. The Appendix contains Illinois pattern jury instructions (IPI) for personal injury (PI) and wrongful death (WD) law discussed in the paper. Economics experts may find these instructions valuable because they provide the language that judges typically use when explaining Illinois law to juries.

\section{Controlling Statutes, Case Law, Court Rules and Pattern Jury Instructions}

Damages in Illinois for PI torts are generally specified by the case law of Illinois courts while damages in wrongful death and improper medical care actions are specified by the Illinois Wrongful Death Act, Survival Act ${ }^{3}$ and Medical Malpractice Acts, with guidance from case law. Expert evidence, to be admissible, must be relevant, i.e. it must establish a fact of consequence to the determination of the pending action. Further, it must be both material and of probative value. (In Re Elias, 1986) An expert's testimony will assist the jury when such testimony offers knowledge and application of principles "beyond the ken of the average juror." (Zavala $v$. Powermatic, Inc., 1995) Evidence is "beyond the ken" of the average juror when it involves knowledge or experience that a juror generally lacks. (Rinesmith v. Sterling, 1997) Following Federal Rule of Evidence 403, which speaks of "prejudice, confusion and waste of time," even if such evidence is arguably relevant, it may still be excluded if it would confuse the issues or tend to mislead the jury. (Cleary and Graham, 1990) The admission of evidence is within the discretion of the trial court and its rulings will be reviewed on an abuse of discretion standard. (Jackson v. Pellerano, 1991) In turn, jury verdicts stand unless contrary to the manifest weight of the evidence. (Voss $v$. Tune, 1984) To be against the manifest weight of the evidence requires that the verdict is clearly erroneous and unreasonable based upon the facts and evidence, (Gilman v. Kessler, 1989), or where, the size of the award is the result of passion or prejudice, the amount is palpably inadequate, or that the jury disregarded proven elements of damages. (Collins v. Straka, 1987)

This section contains the general case law, statutes, and court rules. We make specific comments on the make-whole theory of compensation, collateral source issues, nature of damages, burden of proof, future damages and life expectancy, punitive damages, mitigation of damages, consortium, and per diem arguments.

First, potentially relevant jury instructions are discussed, since forensic economics experts present evidence to jurors typically, and jurors' findings about damages are presented as line item responses to jury instructions.

${ }^{3}$ The text of the Illinois Wrongful Death Act and Survival Act can be accessed at http://fac.comtech.depaul.edu/jciecka/IllinoisWDSA.doc or http://www.legaleconometrics.com 
Statutes and key cases are cited as the need arises; many of the cases are found in the comments and notes on use of the pattern jury instructions.

\section{Make Whole and Collateral Source}

In Illinois case law, compensatory damages for personal injury and wrongful death are based on the "make whole" theory-the object of tort damages is to restore the tort victim as nearly as possible to the position he would have been in had the injury not occurred. (Roberts $v$. Norfolk \& W. $R y ., 1992$ ) As the IPI (see Appendix) indicate, particularly IPI 30.01, with the appropriate specifics from 30.04 through 30.21 added, the jury is given a large amount of leeway in making these determinations. Pursuant to 735 ILCS 5/2-1109, the jury verdict must be itemized.

The collateral-source rule states that benefits received by an injured party from a source wholly independent of, and collateral to, a tortfeasor will not diminish damages otherwise recoverable from the tortfeasor. One application of this principle held that even if an HMO paid rates well below the full reasonable charges, the injured party could recover the full amount. (First Midwest Trust Co. v. Rogers, 1998) This ruling follows the legal theory underlying collateral source rules, namely, that a wrongdoer should not benefit from expenditures made by the injured party, or take advantage of contracts or other relations which exist between the injured party and third persons. Double recovery, also disfavored in the law, may be the lesser of two evils: the Rogers court wrote "although injured parties may receive a windfall from the collateral-source rule, it is usually considered more just for an injured party to receive the windfall than for a wrongdoer to be relieved of full responsibility for his wrongdoing."(pp. 432, 433, First Midwest Trust Co. v. Rogers, 1998) Reinforcing Rogers, the Arthur v. Catour (2004) court determined that an injured plaintiff may recover as damages the entire amount billed for medical services, not merely the discounted amount actually paid by her insurance carrier. Referring to the plaintiff, the Court said "[t]o the extent that she receives an amount greater than that paid by her insurer in satisfaction of the bill, that difference is a benefit of her contract with the insurer, not one bestowed on her by defendants." (p. 806)

Other collateral sources are wage replacements for sick days, short term or long term disability, Social Security disability payments, workmen's compensation payments, and life insurance; although if an employer is the defendant, some of these may arguably not be collateral sources. When workers are injured on the job, the Illinois Workers' Compensation Act, 820 ILCS $^{4} 305 / 1$, permits them to sue the tortfeasors responsible and to receive workers' compensation. If the worker prevails in his personal injury lawsuit, the settlement or judgment received by the worker requires repaying the workers' compensation paid by his employer, 820 ILCS $305 / 5$ (b). The employer may claim a lien on the worker's recovery, in an

${ }^{4}$ ILCS stands for Illinois Compiled Statutes, some of which can be found at http://fac.comtech.depaul.edu/jciecka/IllinoisWDSA.doc or http://www.legaleconometrics.com 
amount equal to the amount of workers' compensation due the worker. 820 ILCS 305/5(b). Section 5(b) of the Workers' Compensation Act provides further that, should the worker prevail, then, from the compensation reimbursed to the employer, the employer must pay its pro rata share of the worker's costs of bringing the litigation and, unless otherwise agreed, $25 \%$ of plaintiff's counsel's legal fees, 820 ILCS 305/5(b).

The general rule for forensic economics experts regarding collateral sources is, if in doubt, to consult with your employing attorney. If he/she is in doubt, be prepared to express opinions that take all possibilities into account.

There are limits to collateral sources, however. In Peterson et al. v. Lou Bachrodt Chevrolet Co. (1979), the Supreme Court affirmed and clarified the law on collateral source issues which apply to medical services. The Court wrote:

The final issue raised by the parties is whether plaintiff may recover the value of free medical services rendered by the Shriners' Hospital for Crippled Children in performing surgery on Mark Peterson's leg. Contrary to plaintiff's argument, we believe that the holding of Jones \& Adams Co. v. George (1907), 227 Ill. 64,669, is still good law and is controlling. In the George case, the court held that a personal injury plaintiff could not recover for the value of nursing services rendered by the plaintiff's family. The reasoning of the decision is sound and, we believe, fully applicable here. An individual is not entitled to recover for the value of services that he has obtained without expense, obligation, or liability. (Accord, Coyne v. Campbell (1962), 11 N.Y.2d 372 at 376, 183 N.E.2d 891 at 893,230 N.Y.S.2d 1 at 4.) We see no need to abandon precedent, as we perceive no erosion of the principle upon which the George case is based; the policy behind the collateral-source rule simply is not applicable if the plaintiff has incurred no expense, obligation, or liability in obtaining the services for which he seeks compensation. This is further made apparent upon comparison of the present case with a situation, in which the collateral-source rule is frequently applied, that of the defendant who seeks a reduction in damages because the plaintiff has received insurance benefits. "It is a well-settled rule of damages that the amount recoverable for tortious personal injuries is not decreased by the fact that the injured party has been wholly or partly indemnified for the loss by proceeds from accident insurance where the tortfeasor did not contribute to the payment of the premiums of such insurance. This rule is usually justified on the basis that the wrongdoer should not benefit from the expenditures made by the injured party in procuring the insurance coverage." (Emphasis added.) (22 Am. Jur. 2d Damages sec. 210, at 293-94 (1965).) In a situation in which the injured party incurs no expense, obligation, or liability, we see no justification for applying the rule. We refuse to join those courts which, without consideration of the facts of each case, blindly adhere to "the collateral source rule, permitting the plaintiff to exceed compensatory limits in the interest of insuring an impact upon the defendant." (Note, "Unreason in the Law of Dam- 
ages: The Collateral Source Rule," 77 Harvard Law Review. 741, 742 (1964) (hereafter Unreason).) The purpose of compensatory tort damages is to compensate (Restatement (Second) of Torts sec. 903, comment $a$ (1979)); it is not the purpose of such damages to punish defendants or bestow a windfall upon plaintiffs. The view that a windfall, if any is to be enjoyed, should go to the plaintiff (Grayson $v$. Williams (10th Cir. 1958), 256 F.2d 61, 65) borders too closely on approval of unwarranted punitive damages, and it is a view not espoused by our cases. (pp. 362, 363)

Illinois statute 735 holds that a judgment in a negligence action against hospitals and physicians can be reduced by up to one-half by benefits that the plaintiff has received from collateral sources, such as private or governmental disability programs. The economic expert report ignores collateral source adjustments, and the trial judge makes them in entering a final verdict upon the proper motion.

Burden of Proof of Damages and Reasonable Methodology of Economic Experts

In Illinois, the plaintiff has the burden of proof as to his damage claims. In cases involving substantial special damages, a forensic economics expert is therefore more likely to be called to testify by the plaintiff rather than the defense. Hence, it is not unusual in Illinois that forensic economics experts show more plaintiff than defense testimonies on their Federal Rule 26 disclosures.

Future Damages and Life Expectancy

Life expectancy tables to support a future damage calculation may be introduced in a personal injury case only if there is evidence that there is permanent injury. In all wrongful death cases (and in some personal injury cases), the issue of joint life survival probabilities has not been specifically addressed. As indicated below, courts have compared individual life expectancies even though, in our opinion, joint survival probabilities may be more appropriate, based on statistical and probability grounds.

Mortality-table related jury instructions arise from IPI 31.13 in wrongful death actions and 34.01 and 34.04 in personal injury. There is a warning in both instructions that life expectancy information is not "conclusive." Instruction 31.13 allows the court to supply the life expectancies of both the deceased and next of kin. In Barry v. Owens-Corning Fiberglas Corp. (1996), the trial judge took judicial notice of mortality tables issued by the U.S. Department of Health and Human Services. He allowed the plaintiff to offer evidence of the life expectancies of the decedent, his wife, and the seven children and gave IPI 31.13 to the jury. In that instruction, the jury was told that in addition to the decedent's life expectancy, it could consider the life expectancies of the widow and the seven children when assessing damages. The defendant contended that where the deceased's life expec- 
tancy is less than the life expectancies of the survivors, allowing the jury to consider the life expectancies of the survivors is inappropriate, confusing, and misleading. The appellate court held that:

\begin{abstract}
The period of time that matters is between the date the decedent actually died and the date he or she would have been expected to die had the defendant's wrongful conduct not intervened. As a matter of logic, if not law, the life expectancy of a survivor should come into play only if it is expected to be shorter than the life expectancy of the deceased. Still, we do not see any harm done by the giving of IPI 31.13. The instruction is permissive. There is no reason to believe the jury was misled or confused by it. Certainly, the plaintiff did not tell the jury it should award money for years beyond Barry's life expectancy. OCF was free to, and did, without contradiction, argue to the jury that the relevant time period was the life expectancy of the decedent, not the survivors. . . There was no error in the giving of IPI 31.13. (pp. 203, 204)
\end{abstract}

The appellate court cited Baird v. Burlington \& Quincy RR Co., (1976), in which the parents of two deceased children sued the railroad under the wrongful death statute, in support of its decision. In Barry v. Owens-Corning Fiberglas Corp. (1996), there was no question concerning the use of the standard mortality tables published by the U.S. Department of Health and Human Services.

In Danzico v. Kelly and James Kelly, (1969), it was deemed proper for the trial court to exclude mortality tables when there is no permanent injury, even if there is a claim for future pain and suffering. The appellate court held "Future pain and suffering, without accompanying a permanent personal injury, is not sufficient in our opinion to permit the introduction of mortality tables which attempt to measure the duration of a given plaintiff's life." (p. 30)

Punitive Damages

In Illinois, punitive or exemplary damages are awarded only when the torts are committed with fraud, actual malice, deliberate violence or oppression, or when the defendant acts willfully, or with such gross negligence as to indicate a wanton disregard of the rights of others. (Consolidated Coal Co. v. Haenni, (1893) at 628) Where punitive damages may be assessed, they are allowed in the nature of punishment and as a warning and example to deter the defendant and others from committing like offenses in the future. Eshelman v. Rawalt, (1921), citing the Restatement (Second) of Torts $\S 908(2)$ (1979). (Punitive damages may be awarded for conduct that is outrageous, because of the defendant's evil motive or his reckless indifference to the rights of others). 
Mitigation of Damages

The general principle of the duty to mitigate damages by taking reasonable actions to minimize them applies in Illinois personal injury cases. (Ross Co. v. Blumberg, 1947) An injured party is bound to exercise reasonable care in seeking and accepting medical aid. (Devlin v. Chicago C.R. Co., 1918) There are limits, and one cannot be required to undergo serious surgery. (Howard v. Gulf, M. \& O. R. Co., 1957) Despite plaintiff having this duty, the defense has the burden to prove as an affirmative defense that such mitigation did not take place. (Williams v. Board of Education, 1977)

\section{Consortium}

The loss of consortium is a claim of damages made by the spouse of an injured person that is separate and distinct from the damage claim of the person who suffered the personal injury. In Illinois, the spouse seeking compensation for loss of consortium must show that he or she suffered damages arising out of the wife's or husband's injuries; it does not follow automatically from one spouse's injuries that the other spouse suffered loss of services. A parent does not have a cause of action for loss of a child's society due to injury to the child. (Dralle $v$. Ruder, 1988) Similarly, a child cannot recover the loss of a parent's society resulting from an injury to a parent. (Karagiannakos v. Gruber, 1995)

\section{Per Diem Arguments}

The per diem argument reduces the calculation of general non-economic damages down to a mathematical formula based on time units and a dollar value of each time unit. The dollar value of each time unit is multiplied by the total number of time units offered (e.g., time units in remaining life expectancy) which gives a total value of damages. Illinois rejects per diem calculations. In Caley v. Manicke, (1962), the court, hearing such an argument, held:

We are of the opinion that an impartial jury which has been properly informed by the evidence and the court's instructions will, by the exercise of its conscience and sound judgment, be better able to determine reasonable compensation than it would if it were subjected to expressions of counsels' partisan conscience and judgment on the matter. (pp. 393, 394)

Another authority is Fintak v Catholic Bishop of Chicago, (1977). 


\section{Lost Earning Capacity}

Illinois' Definition of Earning Capacity

In Illinois PI and WD cases, the valuation of pecuniary losses includes the evaluation of the plaintiff's earning capacity. However, the words "earning capacity" do not appear in the IPI instructions; the closest compensable items appear to be "time" and "earnings." The phrase does appear throughout case law, and the issue facing forensic economics experts is to determine how the courts view the proper use of the term. There are connections to the related concept of worklife expectancy and allied measures, which are discussed in a separate subsection below.

In Antol v. Chavez-Pereda, (1996) the court indicated that the phrase "present cash value of the time, earnings and salaries reasonably certain to be lost in the future" as part of what was then IPI 30.07 Civil (1995) in fact referred to "impairment of the plaintiff's capacity to earn." (p.572) That court said "an award of future lost earnings includes consideration of the extent to which plaintiff's capacity to earn has been impaired. Impairment of earning capacity is the difference between the amount the plaintiff was capable of earning prior to his injury, and the amount he is capable of earning after the injury." (p. 573) also citing Patel v. Brown Machine Co., (1994). We also note that Brown v. Chicago \& North Western Transportation Co., (1987), vacated an award for lack of "reasonably certain proof" to sustain the claim of lost future earnings. This is an old standard that goes back before 1909, where Amann v. Chicago Consolidated Traction Co. (1909) held: "To justify a recovery for future damages the law requires proof of a reasonable certainty that they will be endured in the future," (p. 267) citing Lake Shore and Michigan Southern Railway Co. v. Conway, (1897).

"Reasonable certainty," "lost earning capacity" and "lost future earnings" are linked. What are the evidentiary standards? First, expert testimony is not necessary to establish loss of future earning ability. (Patel v. Brown Machine Co. at 1061) The threshold is relatively low to earn a jury instruction-all that is required to justify the giving of an instruction is that there be "some evidence in the record to justify the theory of the instruction." (Leonardi v. Loyola University of Chicago, 1995) However, the Brown court at 936-37 noted that "mere surmise or conjecture" is insufficient proof of an existing fact or future condition, quoting Stevens $v$. Illinois Central R.R. Co., (1922). Thus, "[p]laintiff may himself testify that his injuries diminished his capacity to work, and the appearance of the plaintiff on the witness stand and his testimony as to the nature of his injuries and their duration is sufficient to take the question of impaired earning capacity to the jury." (p. 360, Shaheed v. Chicago Transit Authority, 1985) Illinois courts require "[e]vidence that plaintiff's injury [is] permanent and that it prevented him from continuing employment [is] generally sufficient to permit a jury to arrive at a calculation of lost future wages." (p. 574, Antol $v$. Chavez-Pereda, 1996) In citing the cases above in LaFever v. Kemlite (1998), the Illinois Supreme Court said: 
....plaintiff need only furnish 'some evidence' probative of his claim to earn a jury instruction on that claim, and neither the trial court nor a court of review must be convinced of the persuasiveness of that evidence before the issue may be submitted to the jury for its deliberations. (p. 407)

The plaintiff wants not just to receive a jury instruction on future earnings, but to prevail. This is a higher standard and a reason for presenting expert economic testimony. Another reason for presenting an economics expert appears in Morris v Milby, (1998); the court wrote:

Once it has been established with reasonable certainty that [plaintiff] would have experienced job advancement, then the speculative nature of testimony regarding the commensurate increases in pay is decreased to a point that its admission is not error. Without such evidence, testimony regarding future earnings based solely upon the [plaintiff's] ambition is speculation and inadmissible.... (p. 230)

citing Carlson v. City Construction Co., (1992). Economics experts may testify about wage growth as well as duration of future loss, and make the associated present value calculations.

We return to the discussion of capacity. The courts have indicated that a worker who is not employed and in fact out of the labor force has the right to be compensated for lost future earnings, and the word capacity captures this idea. Further, capacity is interpreted not as the maximum imaginable, but within reason - earning capacity has quality (rate of compensation) and quantity (number of years, intensity or rate of employment per year) dimensions, and losses may occur in either dimension. For example, injured legal secretaries do not have their capacity calculated as if they were lawyers, or as if they would work to life expectancy. In Christou v. Arlington Park Race Track, (1982) the plaintiff merely had an ambition to become a restaurant owner and simply repeated what he heard some acquaintances say about earnings growth for bartenders. The court deemed this type of "evidence" as inadmissible speculation and could not provide a foundation for a jury instruction on the calculation of lost future earnings based on the average income of restaurateurs and the earnings growth of bartenders. An example of admissible evidence occurred in Long $v$. Friesland (1988):

...plaintiff testified at trial that she had been employed as a legal secretary from 1977 to the spring of 1980. In 1977, she earned $\$ 6.50$ per hour, in $1978, \$ 7.50$ per hour, and in $1979, \$ 8.50$ per hour. Plaintiff did not work after the accident until 1984. At the time of trial, she was employed as a guest service representative at a Holiday Inn, where she worked four hours a day, two days a week. She earned $\$ 4.50$ per hour. She testified that she remains a competent legal secretary, but is only able to work part time due to her injuries. She testified that it is impossible to find a part-time job as a legal secretary. She testified that she did have a full-time secretarial job for a time after the accident, but was forced to quit because of her injuries. Legal secretaries in the area where plain- 
tiff resides earn from $\$ 8.50$ to $\$ 12.50$ per hour. Plaintiff testified that she has difficulty even working a four-hour shift due to her injuries. She must bring three pairs of shoes to work and, by the time she finishes a four-hour shift, she must prop up her right foot and put ice on it to reduce the swelling and pain. Plaintiff presented sufficient evidence from which the jury could determine the amount of her lost future earnings, and it was properly instructed on this element of damages. That plaintiff was voluntarily unemployed at the time of the accident is irrelevant. We think this case is similar to Turner v. Chicago Transit Authority (1984), $122 \mathrm{Ill}$. App. 3d 419, wherein plaintiff sought damages for lost earning capacity, requesting the difference between his salary as a heavy machine operator (the type of work he performed before the accident) and his salary as a light machine operator (the type of work he was limited to performing as a result of the accident). Defendant argued that any such award would be highly speculative because plaintiff had been unemployed at the time of the accident. The appellate court held: 'In our opinion, these periods of unemployment are irrelevant to the determination of lost earning capacity. Whether or not plaintiff was actually employed at either of those specific times, the fact remains that because of the accident, plaintiff is unable to perform the higher-paying type of work he actually did perform prior to [his accident] (122 Ill. App. 3d at 429). (p. 57)

To sum up, the "capacity" concept permits awards to those unemployed or not in the labor force; it also includes the young without an earnings history (as described in the next section).

A commonly observed plaintiff approach appeared in Patel $v$ Brown. Patel could not continue in his pre-injury job, which paid about $\$ 50,000$ per year. He presented no evidence that he could not work at all post accident, only that he could not continue in his previous job. Defense counsel did not hire a vocational expert to pursue an affirmative defense. The court wrote:

He had not worked since his last return to Concord and had not tried to get back to work since that date. His salary at the time of the injury was approximately $\$ 50,000$ a year. In argument to the jury, Patel's attorney said that the measure of damages for future lost earnings was the amount of money Patel was earning, less the amount of money he would be able to get for 'some menial job' and that he 'assumed the plaintiff could find something where he can make $\$ 15,000$ a year.' He argued that the future lost wages should be calculated by subtracting the $\$ 15,000$ from Patel's pre-injury income of $\$ 50,000$ and multiplying the difference, $\$ 35,000$, by the number of working years that remained, 22 years. The jury fixed the amount of future lost earnings at $\$ 770,000$, thus reflecting acceptance of the plaintiff's attorney's argument. (p. 1060)

The court had no problem with this approach taken by the plaintiff, approving the fact that plaintiff 
....did not argue that he could not work at any job or that he was entitled to an annual salary of $\$ 50,000$ for the next 22 years. Instead, he conceded that he was employable at some wage, either twice the minimum wage or some wage below that amount. The defendant saw fit to make a 'nothing at all' argument. We judge that the jury could make conclusions about the nature of Patel's permanent disability and the capacity he had for other jobs in the future based on the testimony of the defendant and Dr. Light. (pp. 1061, 1062)

\section{Earning Capacity of Minors or Young Persons Beginning Careers}

In the case of injury to a minor or young person commencing a career, proof of past earnings cannot come from an earnings history of the individual. A leading case was Singh $v$ Air Illinois (1988). The decedent had graduated from the University of Illinois in 1982. In late 1982, he and his brother formed a business which involved selling computer office management systems to physicians. At age 26, on his way to deliver a system, he was killed. Plaintiff's economics expert based his testimony upon the earnings of the average male Illinois worker of decedent's age and education level. The Singh court wrote:

Despite defendant's assertion to the contrary, such measure of future earning capacity has generally been used in wrongful death actions. (See, e.g., Baird v. Chicago, Burlington \& Quincy R.R. Co. (1976), 63 Ill. 2d 463, Peluso v. Singer General Precision, Inc. (1977), 47 Ill. App. 3d 842. Furthermore, the fact that decedent's actual earning history prior to his death fell below the average for his statistical peer group is of no significance since the proper standard for loss or impairment of future earnings is based upon earning capacity rather than actual earning history. See Robinson v. Greeley \& Hansen (1983), 114 Ill. App. 3d 720. (p. 930)

\section{Earning Capacity of the Self-Employed}

Illinois courts have consistently realized that self-employed persons can have a diminished earning capacity even though they continue to operate their business. In Buckler v. Sinclair Refining Co. (1966), the court wrote: "An increase in salary in a corporate business where the employee is also the manager and majority shareholder has no essential relationship to earning capacity, and therefore, under this state of the record, evidence of actual income was properly excluded.” (p. 294)

\section{Worklife Expectancy}

There is no jury instruction or case law mandating worklife expectancy, but the concept has been generally accepted by Illinois courts and is found in many opinions. Indeed, by combining IPI 34.01 and its phrase "you may consider that some persons work all their lives and others do not" with IPI 
30.07's phrase that present cash value of earnings must be "reasonably certain to be lost in the future," in our opinion future economic losses should not generally significantly deviate from worklife expectancy. However, case specific facts may with additional evidence allow other scenarios.

In Laird v. Illinois Central Gulf Railroad Company, (1991) the court implicitly accepted the concept of worklife expectancy when it wrote "[m]oreover, we do not consider plaintiff's instruction number 18 to be inconsistent with the proposition that future wage loss should be based on work-life expectancy.” (pp. 60, 61)

In Branum v. Slezak Construction Co. (1997), the plaintiff economics expert attempted to calculate future losses for an ironworker out to age 65, with no reduction for mortality, or any other adjustment for time out of the labor force. The defense economics expert used worklife expectancy tables, and testified that the actual worklife expectancy would be less. The trial judge barred the plaintiff's economics expert's testimony, and the appeals court wrote

\begin{abstract}
However, plaintiff fails to point to any evidence that he would have been able to provide any concrete evidence that plaintiff would likely work as an ironworker until the age of 65 . Defendant contends that [the] testimony was properly barred because such testimony would have been speculative and remote because there was no reasonable certainty that plaintiff would have worked and earned income as an ironworker until age 65 . We agree... there is no indication in the record that [plaintiff's economist] would have been able to provide a reasonable basis for his determination that plaintiff could work and earn income as an ironworker until age 65 . Therefore, it is our view that the trial court did not err in preventing such testimony. (p. 960)
\end{abstract}

Whether this court was impressed with ironworkers having less than an average worklife expectancy, we cannot say, but it is clear that merely running calculations out to age 65 or, worse, to life expectancy, fails reasonable standards.

\title{
IV. Discounting to Present Value
}

Instructions 30.07, 30.08, 30.09 (personal injury), 31.12 (wrongful death), 32.03 (spousal services) and 32.06 (child's services to age 18) all speak of present value or present cash value, and the need to discount to determine present cash value. The issue has not been litigated in any depth. IPI instruction 34.02 speaks of present value as an amount which, with interest that it could "reasonably be expected to earn" will equal the future losses. In Richardson v. Chapman (1998), the Illinois Supreme Court held that an economics expert's use of net discount rates of $0 \%$ and $1 \%$ was appropriate and allowable in light of O'Shea v. Riverway Towing Co. (1982). Why a federal case would be relevant to an Illinois Supreme Court which had earlier rejected federal guidance on taking income tax deductions into account is unclear. Further, the Riverway court did not comment on the 
kind (e.g., U.S. Treasury) or duration (e.g., one year) of the securities in its decision; rather it noted that the method behind the calculation required not mixing nominal and real wage and interest rates. The jury instruction IPI 34.02 indicates only that the interest rate must generate a sum that may "reasonably be expected" to be earned.

Varilek v. Mitchell Engineering Co. (1990) and Stringham v. United Parcel Service, Inc. (1989), hold that economics experts may take inflation into account or net it out and use real rates. These cases correct American National Bank v. Thompson (1987), which had required nominal interest rates in discounting to present value without permitting nominal wage growth—precisely the error cautioned against in O'Shea.

\section{Fringe Benefits}

The Illinois courts have had little to say regarding fringe benefits other than to consistently recognize them as a part of earning capacity. In Antol $v$. Chavez-Pereda, the appellate court affirmed a jury award of $\$ 636,000$ composed of $\$ 563,000$ in lost earnings and $\$ 73,000$ for lost fringe benefits in which the main evidence on money earnings and fringe benefits was provided by a union representative. The appellate court referred to the composite of lost money earnings and fringe benefits as simply "lost earnings." It said, for the recovery of "lost earnings, all that the law requires is evidence that will establish, with a fair degree of probability, a basis for assessing damage." (p. 573) Therefore, the same evidentiary hurdle and compensatory suitability would seem to apply to what an FE would call "money earnings" and "fringe benefits."

The value of lost benefits in the pre-trial period and the present value of "benefits reasonably certain to be lost in the future" are clear components of IPI 30.07 for damages for personal injury. In addition, IPI 31.01 to 31.07 for the wrongful death of children and adults all mention the loss of benefits. They differ in regard to the presumption of substantial pecuniary loss on the basis of whether the surviving party is a spouse or lineal next of kin (where there is a presumption of loss) or a collateral next of kin (where there is no presumption of loss). Similar recovery can occur in a survival action; but, of course, there can be no double recovery of damages under a survival action and wrongful death for any specific period of time. In a wrongful death action from an accident in 1965, a jury verdict in 1977 (American National Bank and Trust Co. of Rockford, Adm'r of the Estate of Carolyn McClellan v. Robert Bourland, Adm'r of the Estate of Richard Boigenzahn, 1978) included lost fringe benefits. Testimony was properly allowed on the value of those benefits in 1965 and their value in 1977. In determining damages, the appellate court observed that "a jury may consider what a decedent earned or might reasonably be expected to earn in the future" which included the value of fringe benefits. (p. 980)

In an FELA case, wherein Illinois courts' rules on substantive issues follow federal law, but also follow the law of the forum for procedural issues, Edwards v. Atchison, Topeka and Santa Fe Railway Company (1997), 
the court followed the methodology of an Ohio and a Missouri court in remanding an economics expert's calculation of lost Tier II railroad pensions. Citing Rachel v. Consolidated Railroad Corp. (1995) the court quoted it as follows:

Pursuant to the Railroad Retirement Act of 1974, 45 U.S.C. $§ 231$ et seg., the Railroad Retirement Board administers disability and retirement annuities for eligible railroad workers, paid from a fund maintained by the United States Treasury. The internal revenue code requires employees and employers alike to contribute tax payments to the annuity fund. 26 U.S.C. $\S \S 3201,3221$. Both employees and employers presently pay an amount equal to $7.65 \%$ of the employee's gross wage in 'Tier I' taxes, which taxes sustain the Railroad Retirement Board Disability and Retirement Annuities that supplant social security benefits. The employee pays an additional $4.9 \%$ of his total compensation as a 'Tier II' tax toward the retirement fund's pension component, and the employer adds an amount equal to $16.1 \%$ of the employee's compensation in Tier II taxes. (p. 429)

Rather than use $16.1 \%$ as a fringe benefit percentage, the court noted that

Defendant insists, and the Court must agree, that the total tax contributions by the parties do not fairly approximate the value of Plaintiff's loss. Defendant aptly quotes the Missouri court in $A d$ ams v. Burlington Northern R.R. Co., 865 S.W.2d 748, 750 (Mo. Ct. App. 1993): 'Any link between the taxes paid and the benefits is too tenuous to provide a true measure of plaintiff's loss.' Congress determines the size of the tax contributions and the size of Plaintiff's annuity, and it has no obligation to balance the two. (p. 430)

There was no connection between total employer and employee contributions and benefits actually accruing to the plaintiff. Instead, the court required that the plaintiff's lost retirement benefits be calculated by applying the retirement annuity formula in order to arrive at two numbers: (1) the amount plaintiff would have been entitled to if he had continued to work until an assumed retirement age, and (2) the amount to which the plaintiff will actually be entitled. The plaintiffs' lost benefit, according to the court, would be the difference between the two amounts, discounted to present value.

Other fringe benefits, such as pension plans in the private sector (especially in defined contribution plans), may not suffer from the gross distortions between costs and benefits present with the Railroad Retirement Board annuity and to a lesser extent with Social Security. 


\section{Income Taxes}

In all non-FELA ${ }^{5}$ PI and WD cases within the State of Illinois, the courts have held that giving a jury instruction that any award was not subject to federal or state income taxes would constitute presumptive prejudicial error which may have tended to influence the amount of the verdict. One early such case was Hall v. Chicago \& N.W. Railway Company (1955). This case states what continues to be the Illinois position on subtraction of taxes from lost earnings: they are not subtracted in either personal injury or wrongful death actions.

The U.S. Supreme Court case Norfolk \& Western Ry. Co. v. Liepelt (1980), required that income taxes be considered in FELA cases. Gulf Offshore Co. v. Mobil Oil Corp. (1981), followed a year later, and the holding was extended to all federal common law cases. It became natural to ask whether Illinois would conform its state law to the federal standard. The answer was articulated in Klawonn v. Mitchell (1985), in the form of a ruling on jury instructions. The Illinois Supreme Court held that defendants were not entitled to a jury instruction that tort awards are not subject to federal or state income taxes. The court said: "In our opinion proof of pecuniary loss, not simple under the best of circumstances, should not be rendered more complex by injecting the question of income tax or other extraneous factors." (p.458) Justice Blackmun's Liepelt dissent became the majority position in Illinois. Why income taxes should be excluded from the purview of expert opinion when other subtle areas such as interest rates, wage growth, worklife expectancy and an appropriate earnings base are allowed is difficult to justify. We find the Klawonn dissent of Justice Ryan quotable:

The opinion in this case creates an absurdity in the law which I am sure will cause the public to figuratively shake its head in bewilderment and to express disgust with the courts and the legal profession. If a person is injured in an accident involving the Federal Employers' Liability Act, a jury must be told that the award is not subject to Federal income tax, whereas if the same person is injured in an accident covered by State law, a jury cannot be told that the award is not subject to the tax. The tax consequences are exactly the same in both situations. So, as a layman, Mr. Lawyer, I would ask you, please explain the reason for the difference in the treatment of these two claims. As a lawyer, Mr. Layman, I can only answer it is so because the Illinois Supreme Court said it is so. (pp. 458.459)

The Illinois affirmation of the holding of Klawonn on jury instructions was extended to the questioning of the economics expert in his calculations in Suich v. $H \&$ \& Printing Company, Inc. (1989), citing McCann v. LisleWoodridge Fire Protection District (1983). Suich v. H \& B Printing Com-

${ }^{5}$ Other cases follow FELA law as well, such as Jones Act cases and DOHSA (Death on the High Seas Act) cases. 
pany, Inc. held that "evidence of the effect of taxes on income loss should be prohibited in a personal injury action."

\section{Household Services}

Like fringe benefits, the Illinois courts have had little to say regarding household services other than to consistently recognize them as a part of damages in personal injury and wrongful death. The comments attached to IPI 30.07 (for lost earnings and profits for adults due to personal injury) indicate that "homemaker's lost services are a proper element of damages if value of lost services is established" and cite McManus v. Feist (1966). However, the appellate court in that case upheld a verdict that did not include damages for lost household services because no evidence was presented at trial on the value of such services and, absent such evidence, concluded that "such element of damage could only be determined by indulging in speculation and conjecture." On the other hand, this decision seems to recognize lost household services as compensable if established by evidence. IPI 30.07 refers to the value of lost time, earnings, profits, salaries, and benefits; presumably lost household services would be part of "benefits" or possibly "time."

Comments to Instruction 32.03 (for past and future injury to a spouse) indicate that damages to the husband for loss of services of his wife and for a wife suing to recover for her loss of services where a husband has suffered bodily injury are compensable in Illinois. The case law cited is Manders $v$. Pulice (1968) and Dini v. Naiditch (1960). In the first of these cases, the appellate court wrote:

Illinois recognizes a separate cause of action in the husband's name where, by reason of injuries to his wife, the husband has been deprived of her services as his wife, and has suffered and sustained a loss of her consortium, or has been put to expense which was not recovered in a suit by the wife. Consortium in Illinois is comprised not only of material services.... (p. 474)

This case recognizes a separate cause of action for a spouse for household services and indicates that such services, when lost to a spouse, are part of a consortium claim. In Dini v. Naiditch at 430, the right of a wife to compensation for the loss of consortium (of which household services are part) was established, although this right had been denied in common law. In 1977 in Wood et al.v. Mobil Chemical Company, the court specifically upheld issuance of IPI 32.03 and a wife's right to recover for lost consortium, which now included lost household services, due to the injury of her husband.

Johanek et al. v. Rigsby Truck Lines (1987) involved, among other issues, a wife's claim for loss of consortium stemming from an injury to her husband. Johanek's wife testified that he could not perform any household services after he was injured. The wife had dropped her claim of impaired sexual relations, and the appellate court, upon remittitur of $\$ 380,000$, af- 
firmed consortium losses of $\$ 500,000$. While consortium, sans impaired sexual relations, still consists of several items, including household services, there is no record of the plaintiffs making any payments to replace household services lost between Jonanek's injury and the date of trial, yet the loss was compensable.

The Illinois Wrongful Death Act creates a cause of action for the benefit of a widow, or widower, and next-of-kin for "pecuniary injuries" which includes loss of services. When there are surviving children, this includes instruction, moral training, and guidance of their development into adulthood. Pecuniary loss 6 includes loss of consortium, which, in turn, includes the loss of household services when there is a surviving spouse. IPI 31.01 to 31.07 for the wrongful death of children and adults all mention the loss of services. They differ in regard to the presumption of substantial pecuniary loss on the basis of whether the surviving party is a spouse or lineal next of kin (where there is a presumption of loss) or a collateral next of kin (where there is no presumption of loss). Similar recovery can occur in a survival action.

In a wrongful death action from an accident in 1965, a jury verdict in 1977 (American National Bank and Trust Co. of Rockford, Adm'r of the Estate of Carolyn McClellan v. Robert Bourland, Adm'r of the Estate of Richard Boigenzahn, 1978), included the value of housekeeping services of a deceased mother. Testimony was held to have been properly allowed on the value of a "female live-in helper" in 1965 and what the value of such services were in 1977. In determining damages, the appellate court observed that "the value of a live-in housekeeper at the time of trial speaks to the expense to replace those services which otherwise would have been performed by decedent" (pp. 980, 981) and concluded that such information was relevant to the jury.

We also provide references to household services as a component of damages in Effects of Re-Marriage in Section XI.

\section{Personal Consumption}

The concept of a personal consumption offset is implicit and not explicit since it does not appear in the Wrongful Death Act. Since economics experts often employ a "top down analysis" and determine loss to survivors as the difference between total income and that personally consumed by the decedent, wording involving a personal consumption offset has found its way into Illinois case law. Whether family income or only the decedent's income is the subject of such an offset has been discussed by forensic economics experts, but not decided definitively in Illinois in any case we can find. We have located the 1928 case Wilcox $v$. Bierd (1928), which we quote

${ }^{6}$ Before Bullard (1984), cited below, this term referred to money or what could be valued with money, i.e., translated into an economic loss. The Illinois Supreme Court, with no help from the General Assembly which wrote the Wrongful Death Act and limited damages to pecuniary losses, simply re-defined the term, to include what in other states and in the federal courts are called non-pecuniary losses. 
below at length, both for whatever guidance it may offer on this point, and also for its re-enforcement of the capacity and earnings connections discussed earlier. The Wilcox court cited Chicago, Peoria and St. Louis Railroad Co. v. Woolridge (1898) and wrote:

\begin{abstract}
Pecuniary loss is held, as to lineal kindred, to mean what the life of the deceased was in a pecuniary sense worth to them, and such loss is to be determined from proof of the personal characteristics of the deceased, his prospects in life, his mental and physical capacity, his habits of industry and sobriety, and the amount of his usual earnings, as proof of what he might in all probability earn for the future support of his wife and children. The amount to be recovered is the pecuniary value of such addition to his estate as the deceased in reasonable probability would have made and left, if his death had not been wrongfully caused. It is to be estimated by the jury from all the facts and circumstances proved. It was further held in that case that the poverty, wealth, helplessness or dependence of the lineal next of kin is immaterial on the question of the amount of the recovery under the statute. Those features are not at all to be considered in measuring or estimating the loss sustained or in determining the liability, in case of lineal kindred, when there is death caused by a wrongful act. It is also wholly immaterial whether such next of kin had or had not other pecuniary resources after his death. (pp. 580, 581, italics added)
\end{abstract}

As soon as pecuniary resources are understood to include human as well as non-human capital, and helplessness or dependence is understood to include consideration of a second breadwinner, it would appear that the personal consumption offset would be calculated from decedent's income alone. On the other hand, an economics expert views money as fungible, and may estimate decedent's consumption with respect to family income. In light of the legal issue being open, our practice has been to discuss the matter with our employing attorney when it arises.

\title{
IX. Medical Expenses and Life Care Plans (LCP's)
}

In Illinois, medical expenses and life care plans are covered under IPI 30.06 , and constitute an allowable element of damages following a long sequence of cases. In some states, the medical costs being evaluated must be prescribed by an M.D. In Illinois, we have M.D.'s who vertically integrate and write plans, others who consult with R.N.'s, and life care planners who have neither designation, but often some other credential. The foundational basis of a life care report was the subject of Compton $v$. Ubilluz et. al. (2004). The trial court barred the proffered expert "from testifying to any of plaintiff's future health care needs that required a physician's prescription or order" because the proffered expert was not a physician. The appellate court wrote: 
We agree with plaintiff that, once her physicians testified that her condition was caused by defendant's breach of his duty to diagnose and treat plaintiff, there was an adequate foundation for Spector's testimony regarding treatment options that did not require a physician's prescription. We note that defendant did not take the opportunity to introduce his own evidence that Spector's recommendations addressed symptoms for which defendant was not responsible. Testimony offered by expert witnesses is to be judged by the same rules of weight and credibility applied to testimony of other witnesses, which are questions of fact for a jury, and, in the absence of evidence to the contrary, the jury chose to credit Spector's opinions in this case. (p. 867)

It appears to be a common practice that life care planners base medical elements of their plans on physicians' records and interviews. See Morus $v$. Kapusta (2003).

\section{Hedonic Damages}

The admissibility of hedonic damages has not been authorized in the State of Illinois. In fact, the following two cases show that a judge's decision not to allow this testimony does not violate an abuse of discretion standard.

In Fetzer $v$. Wood (1991), a wrongful death case, the appeals court wrote

However, it is well settled that, with respect to damages for pain and suffering, i.e., nonpecuniary damages, it is improper for counsel to suggest that the jury calculate such damages by placing a dollar figure upon each minute, hour or day as to which pain and suffering was or will be experienced, since such argument presents an illusion of certainty (Caley v. Manicke (1962), 24 Ill. 2d 390, 393-94). (p. 84)

Thus it used a per diem argument as one basis to bar hedonic damages testimony. The court then came up with a second reason not to allow this testimony.

The determination as to the admissibility of evidence rests primarily in the discretion of the trial court, and its decision will be reversed only where that discretion clearly has been abused. (Country Mutual Insurance Co. v. Adams, 85 Ill. App. 3d 501, 506 (1980).) Here, the proposed economic expert testimony would be overly speculative and would serve to invade the province of the jury, and we see no abuse of discretion in the exclusion of such evidence. (p. 85, 86)

We could see defense attorneys quoting the court's use of the words "speculative" and the phrase "invad[ing] the province of the jury" while plaintiffs' counsel characterize the court's words as dicta.

In Patch v. Glover (1993), the Illinois Court of Appeals again upheld a trial court decision not to admit hedonic damage testimony about loss of 
society. The First District of the Appeals Court, which includes Cook County, said: ${ }^{7}$

We believe that ....-'s proffered testimony on the value of the loss of society was marginally relevant, potentially confusing, and misleading... The only attributes of Patch that entered into -.---'s calculations were his age, sex, and race. -..-- admits that the value society places on the non-monetary contribution of the statistically average person inures to the benefit of those who have an immediate relationship with the person.... [--..-'s testimony] would serve no purpose other than to distract the jury from its real task which is to apply their collective common sense to assess the value of the society lost by plaintiff and the children. Moreover, -.---'s testimony on this issue would mislead the jury into believing the false notion that the distinct and personal relationship that one has with his wife and children has commercial value which can be determined by a comparison to the value that society places on the non-monetary contributions of the statistically average person. ..It is our belief that the type of evidence that plaintiff sought to introduce through -..--'s testimony would be the antithesis of a reasonable and practical consideration of the fair and just compensation for the loss of society suffered by the spouse and next of kin of a decedent under the peculiar facts of any given case. (pp. 568, 569, italics added)

Between these two decisions, the two courts had articulated several reasons for not permitting hedonics testimony. Finally, in Gonzales v. City Wide Insulation (1990), the U.S. District Court, interpreting Illinois law, ruled that the Illinois Wrongful Death Act does not provide for the recovery of hedonic damages. The practical result of these opinions has been a dramatic falloff in the willingness of plaintiffs' attorneys to procure hedonic damages opinions.

\section{Miscellaneous Issues of Interest to Forensic Economics Experts}

\section{Illinois Court System Background}

The highest tribunal in the state is the Supreme Court, with offices in Springfield and Chicago. There are seven justices, representing each of the five judicial districts. Each justice serves for a term of 10 years. Three justices are elected from the First District (Cook County), and one from each of the other four districts. The Supreme Court has general administrative and supervisory authority over all courts in the state and its various rules. ${ }^{8}$ The Supreme Court hears appeals from lower courts and may exercise original

${ }^{7}$ The Court used the expert's surname, but it is redacted here.

${ }^{8}$ Rules important to FE's can be viewed at http://fac.comtech.depaul.edu/jciecka/Rules.doc or http://www.legaleconometrics.com 
jurisdiction in cases relating to revenue, mandamus, prohibition or habeas corpus.

The legal researcher new to Illinois law should be aware of Rule 23 of the Supreme Court according to which appeals court decisions may be (a) opinions; or (b) written orders; or (c) summary orders. ${ }^{9}$ The latter two cannot be cited for precedent, although they may be persuasive. By Rule 23 there are limits on how many full opinions can be issued per year per District. In fact opinions may contain non-publishable parts, which will appear between markers indicating the deletions. Another non-obvious point is the idea of "one appellate court": when any District has ruled on a point, it is law in other Districts as well, until those other Districts either follow it or conflict with it. The Illinois Supreme Court explained this in Aleckson $v$. Village of Round Lake Park (1997):

Illinois has but one appellate court. People v. Granados, 172 Ill. 2d 358,371 (1966). Although the state is divided into five judicial districts, those districts have nothing whatever to do with the court's authority. Their sole purpose is to define the political units from which judges of the supreme and appellate courts are selected. Ill. Const. 1970, art. VI, § 2. (p. 94)

History of Wrongful Death Law

Since February 12, 1853, all tort actions for wrongful death in Illinois exist by statute; no cause of action had existed at common law. The Illinois General Assembly enacted 740 ILCS (S.H.A.) 190/0.01, copying New York's 1847 statute, which in turn had enacted from England sections 9 and 10 Victoria, Chapter 93, commonly known as Lord Campbell's Act (August, 1846). For over almost 90 years, recovery was limited to $\$ 5,000$, but the there were increases to $\$ 10,000$ (1935), $\$ 15,000$ (1947), $\$ 20,000$ (1951), $\$ 25,000$ (1955) and $\$ 30,000$ (1957). Amendments in 1965 required the jury to determine damages without regard to dollar limits, while maintaining the cap on the actual award. In 1967, the cap was lifted. The purpose of the act is to provide support for the surviving spouse and next of kin for the economic or pecuniary benefits they would have received had the decedent continued to live. Actions are brought in the names of the personal representatives of the deceased person-administrators if the person had died intestate or executor if the person left a proper will. Punitive damages are not recoverable under this act, and that has been held to be constitutional by the U.S. Seventh Circuit in 644 F. 2 d 594.

Actions must be brought within two years, and next of kin means just that-spouses; children (biological, adopted, foster and posthumous); and then parents and siblings (following down Illinois' Statute of Descent, 755 ILCS 5/2-1); not included are ex-spouses, fiancés, live-in lovers, co-habitants and the like.

${ }^{9}$ See http://fac.comtech.depaul.edu/jciecka/AppellateCourt.doc or http://www.legaleconometrics.com for information about the disposition of cases in the Appellate Court in Illinois. 
One must distinguish wrongful death actions from survival actions. Since tort actions in the common law cease with the death of either party, Olson v. Scully (1921), it took a statute to remedy the situation to permit actions to recover damages for an injury to a person to survive his death. The modern reference is given above, 755 ILCS 5/1-1 et seq, \#27-6 of the Probate Act of 1975.

Death of Children

The most relevant case regarding assignments an $\mathrm{FE}$ might receive involving the death of a child is Bullard v. Barnes (1984). In this case, the Supreme Court held:

In its current form the presumption of pecuniary loss no longer conforms to this definition. We therefore hold that in this case, and in all similar cases not finally adjudicated, there can be no presumption of loss of earnings upon the death of a child since such a presumption represents an aberration from, rather than a reflection of, the typical family experience. However, we have concluded that parents are entitled to a presumption of pecuniary injury in the loss of a child's society, based on the holding expressed earlier in this opinion that the pecuniary injury for which parents may recover under the wrongful death statute includes this form of loss. Defendants may rebut the presumption by presenting evidence that a parent and child were estranged. Although the presumption of a loss of earnings no longer applies, in the rare case where the child earned income that was used to support the family these facts may, of course, be proved and a recovery had. This case does not present, and we therefore need not decide, the question of whether the loss-of-society presumption applies to children who have reached the age of majority. (p. 517)

We find Justice Clark's specially concurring opinion interesting:

First, I do not agree with the majority's application of a setoff for child-rearing expenses. Although some jurisdictions have adopted such a setoff (S. Speiser, Recovery for Wrongful Death sec. 4:25 (2d ed. 1975)), I do not believe that this is an equitable formula to use in computation of damages. In the case at bar, damages were awarded for the loss-of-society count of the complaint. Since plaintiff's decedent was 17 years old at the time of his death, a setoff for college tuition and living expenses could substantially reduce the loss-of-society award. Second, I believe that the majority should consider whether the loss-of-society presumption applies to children who have reached the age of majority. I would not limit this opinion to minor children, since I believe the logic embodied in the majority opinion would dictate a similar result if this case involved a 27-year-old rather than a 17-year-old. In the case at bar, plaintiff's decedent was at a point in his life where his parents could reasonably anticipate receiving advice, companionship and assistance. This presumption is equally valid for adult and minor children. Although I disagree with 
these two aspects of the majority opinion, I am heartened that the court has decided to extend Elliott v. Willis (1982), 92 Ill. 2d 530, to discard an inequitable distinction that began with English interpretations of Lord Campbell's Act. (p. 521)

In a personal injury to a child case, to the extent that all future earnings capacity were extinguished, the child or court approved representative would have a right to sue, and such earnings could be calculated. In regard to loss of consortium claim, Dralle v. Ruder (1988) indicates that parents of a non-fatally injured child would have to provide evidence of reduced society and companionship due to the injury. Then a jury or judge would have the extremely difficult task of assigning a monetary figure to that loss.

\section{Prejudgment and Post-Judgment Interest}

In Alguire v. Walker (1987), the court recognized that prejudgment interest was not awardable absent statutory or equitable grounds when not agreed upon. This is one reason that prejudgment interest is unavailable in personal injury and wrongful death actions. Additionally, the damages must be liquidated (readily determinable) to come within the provisions of section 2 of the Interest Act, and the very presence of expert testimony is inconsistent with liquidation. Further, the Interest Act (Ill. Rev. Statutes, Ch. 74, \#2) does not so authorize interest, for personal injury torts or for the Wrongful Death Act. Interest Act (Ill. Rev. Stat. 1977, ch. 74, par. 2). Section 2 states that:

[c]reditors shall be allowed to receive at the rate of five (5) per centum per annum for all moneys after they become due on any bond, bill, promissory note, or other instrument of writing; on money lent or advanced for the use of another; on money due on the settlement of account from the day of liquidating accounts between the parties and ascertaining the balance; on money received to the use of another and retained without the owner's knowledge; and on money withheld by an unreasonable and vexatious delay of payment.

Where warranted, the sum due must be liquidated or subject to an easy determination by calculation or computation. (Couch $v$ State Farm Insurance, 1996) Whether to award prejudgment interest pursuant to the Act is a matter within the sound discretion of the trial court, and its decision will not be reversed absent an abuse of discretion. (Gray v. Mundelein College, 1998) The Illinois Supreme Court has determined that prejudgment interest, where warranted, is a means of compensating injured parties for any economic loss suffered, but is not intended to be used as a sanction against the wrongdoer. (In re Estate Wernick, 1989)

Post judgment interest, on the other hand, applies generally, and so to personal injury and wrongful death claims. Section 2-1303 of the Code of Civil Procedure (Ill. Rev. Stat. 1985, ch. 110, par. 2-1303) permits simple 
interest at the rate of $9 \%$ to accrue on final judgments ${ }^{10}(6 \%$ when the judgment debtor is a unit of local government), from the date of its entry until the date of its payment, to compensate the judgment creditor for delays during which he is denied use of the judgment amount. (Carswell $v$. Rosewell, 1986)

There appears to be no economic justification for the $9 \%$ (for post judgment interest) differing from the 5\% (for pre judgment interest when allowed) except perhaps to offer a disincentive to appeal and to hasten payment of the judgment; in both cases, these rates differ from federal rates, which in the Northern District of Illinois tend to float with the market-one year treasuries and prime rates have been permitted for prejudgment interest.

Annuity Testimony and Ultimate Issue Testimony

Illinois courts have not been kind to annuity testimony. In Exchange National Bank of Chicago v. Air Illinois, Inc. (1988), the court again upheld a trial court barring a defense annuity broker from attesting to the cost of an annuity. The court cited Singh v. Air Illinois, Inc. (1988), and concluded that: ${ }^{11}$

in light of our Supreme Court's admonition that annuity testimony should be presented only with neutral figures to describe a mathematical process to aid the jury in determining present value (Allendorf v. Elgin, Joliet \& Eastern Ry. Co. (1956), 8 Ill. 2d 164, (1956)), it was not error for the trial court to preclude its admission. We also noted in Singh that as an insurance broker relying on final quotations from outside sources, -..-- could not be effectively cross-examined as to the basis of his figures. For these reasons, -.---s testimony was properly barred here.... (p. 1088)

The ruling in Allendorf $v$. Elgin, Joliet \& Eastern Ry. Co. (1956) prevented economics experts as well as actuaries from testifying to a bottom line or ultimate issue opinion. However, in discussing an economics expert's testimony in Richardson v. Chapman (1998), the court wrote:

the basis for the neutral-figure requirement expressed in that case was the prohibition against opinions on the ultimate issue....Subsequent cases have removed that bar, however, and have determined that a witness, whether expert or lay, may provide an opinion on the ultimate issue in a case. Zavala $v$. Powermatic, Inc., 167 Ill. 2d 542, (1995); People v. Harris, 132 Ill. 2d 366, 385, (1989); Freeding-Skokie Roll-Off Service, Inc. v. Hamilton, 108 Ill. 2d 217, 221, (1985); Merchants National Bank v. Elgin, Joliet \& Eastern Ry. Co., 49 Ill. 2d 118, 122, (1971). The trier of fact is not

${ }^{10}$ The Illinois statute that governs post judgment interest does not indicate simple or compound accrual. However, we have found some information indicating that simple interest is used.

${ }^{11}$ The Court used the expert's surname, but it is redacted here. 
required to accept the expert's conclusion, and therefore such testimony cannot be said to usurp the province of the jury. Zavala, 167 Ill. 2d at 545; Merchants National Bank, 49 Ill. 2d at 122. Because the rule against opinions on the ultimate issue no longer has any vitality, we believe that its corollary, which would require the use of neutral figures in presenting the jury with testimony about present cash values, has similarly lost its foundation. (pp. 107, 108)

Bringing these holdings together, it is our opinion that there is no reason that the same reasoning today should not permit an actuary or properly trained economics expert from testifying about annuities. That said, if the annuity properly replaces the income stream it is intended to replace, and the person on whose life contingency the annuity pays is representative, there should not be a major difference between economic and annuity testimony; where the life is substandard in an underwriting sense, such annuity testimony could be usefully presented, but someone will need to establish the precedent.

\section{Increased Risk of Harm and Lost Chance of Survival/Recovery}

These two areas of the law represent an exception to the "more likely than not" preponderance of the evidence requirement. IPI 30.04 .03 and 30.04 .04 speak to the situation where there is less than a $50 \%$ probability that some future harm is likely to occur. Dillon v. Evanston Hospital (2002) established that multiplication of the damages under certainty by the percentage likelihood of the harm is the appropriate method of calculation.

A related calculation is relevant where, but for a missed diagnosis, a person had a less than 50\% chance of survival. In Liebig-Grigsby $v$. United States (2003), interpreting Illinois Law, the District Court held that a "lost chance of recovery" case should follow the formula in Doll v. Brown (1996):

The trier of fact will estimate the probability that the patient would have survived but for the physician's negligence - say it is 25 percent - and will award that percentage of the damages the patient would have received had it been certain that he would have survived but for the negligence. (p. 47)

The Illinois Supreme Court had earlier held that the "lost chance theory" applied in Illinois in Holton v. Memorial Hospital (1997). In Liebig-Grigsby (2003), the Court held that testimony indicated that there was a $70-80 \%$ chance of halting further deterioration in the plaintiff's condition and multiplied damages based on $100 \%$ causation by the average of $75 \%$.

\section{Illinois Malpractice Act of 1985 and Periodic Payments}

The Illinois Medical Malpractice Reform Act of 1985, Public Act 84-7, quickly saw five key provisions challenged in Bernier v. Burris (1986). The Bernier court determined that the establishment of review panels in medical malpractice cases violated provisions in the Illinois Constitution with 
respect to the source of judicial power and the jurisdiction of the circuit courts, at 233 , but that the periodic payment of certain damages, the modification of the collateral source rule in medical malpractice actions, the elimination of punitive damages in actions for medical malpractice, and a sliding scale of the allowable fees an attorney may charge in representing a medical malpractice plaintiff were all constitutional, since they were rationally related to the legitimate government interest of "reducing the burdens existing in the health professions as a result of the perceived medical malpractice crisis." (Bernier v. Burris, at 252)

If the provisions of this act are elected and future payments exceed $\$ 250,000$, the jury will determine the nominal flow of future damages, and the court will discount them at 6\%, cf. the Ill. Code of Civil Procedure, Article 2, Part 17. Neither author of this paper has seen a case where this provision was elected, nor can we find a single reported case discussing the periodic payments provisions of this legislation. To our puzzlement, this appears to be a non-issue, despite the zero-sum character of litigation. The periodic payments requirements of New York State's 50-A and 50-B have not come to Illinois.

\section{More Recent Illinois Malpractice Acts}

The Civil Justice Reform Amendments of 1995, P.A. 89-7, attempted to change the law of medical malpractice in several important ways that favored defendants, but the Illinois Supreme Court held this to be unconstitutional in its entirety. (Best v. Taylor Machine Works, 1997) In referencing annotated statutes, the reader should check to make sure that the unconstitutional parts are noted or deleted. Below we cite 735 Ill. Comp. Stat. Ann. § 5/2-1114, 1115, and 1205 .

We do not discuss issues pertaining to the statute of limitations, Illinois' modified comparative negligence, joint and several liabilities, or hospitals' vicarious liability for the acts of physicians following Petrillo $v$. Syntex Laboratories (1986). There had been no cap on compensatory damages, but punitive damages are not allowed, before very recent legislation, and prior to 1995 . In the 1995 attempt at tort reform, the Illinois legislature passed a $\$ 500,000$ limit on non-economic damages in medical malpractice cases, 735 Ill. Comp. Stat. Ann. § 5/2-1115.1. The Best decision did not disturb the preexisting statute prohibiting punitive damages in medical malpractice cases. (735 Ill. Comp. Stat. Ann. §5/2-1115) An attorney's contingent fee in a medical malpractice case may not exceed (a) $33-1 / 3 \%$ of the first $\$ 150,000$ recovered, (b) $25 \%$ of the next $\$ 850,000$ recovered, and (c) $20 \%$ of any amount over $\$ 1,000,000$. However, if the claimant's plaintiff lawyer can show extraordinary services involving more than the usual time and effort, he/she may petition the court for additional compensation. (735 Ill. Comp. Stat. Ann. § 5/2-1114) Illinois has a modified collateral source rule which is applicable to medical malpractice cases only. Upon application by the defendant within 30 days after judgment, the award will be reduced by the following amounts: (a) $50 \%$ of the lost wages or disability income paid or 
payable to the claimant in relation to the injury by another person, corporation, or insurance company; (b) 100\% of the medical, hospital, and nursing charges paid or payable to the claimant in relation to the injury by another person, corporation, or insurance company. (735 Ill. Comp. Stat. Ann. § 5/21205) Such a reduction of a claimant's recovery by collateral source payments, however, is limited by the following rules: (a) there can be no reduction for amounts paid by a person with a right of subrogation against the judgment; (b) the judgment may not be reduced by more than $50 \%$; (c) the damages awarded must then be increased by insurance premiums or direct cost paid by the claimant; and (d) there is no reduction for medical expense directly attributable to the adjudged negligent act or omission of the defendant.

Over Memorial Day weekend in 2005 the Illinois House and Senate again approved medical malpractice legislation which the Governor signed. The new law caps non-economic damages, e.g., pain and suffering and loss of consortium, at $\$ 500,000$ in a malpractice case against a physician and $\$ 1$ million in a malpractice case against a hospital. This law is currently being challenged in the courts by litigants in LeBron v. Gottlieb.

To sum up, in our opinion an economic expert should calculate losses in medical malpractice matters in the same manner as in other tort cases. Courts may make certain adjustments like modifying collateral source rules, but that need not concern a FE. If the special provisions of the 1985 malpractice act which require calculating nominal flows were to come into play, the retaining attorney would inform the FE; but, as previously mentioned, neither author is aware of such a case.

\section{Illinois Remains a Frye State Regarding Expert Testimony}

The most recent opinion of the Illinois Supreme Court on this subject is Donaldson v. Central Illinois Public Service (2002), "Illinois law is unequivocal: the exclusive test for the admission of expert testimony is governed by the standard first expressed in Frye v. United States (1923)." (pp. $76,77)$ The court elaborates that:

The Frye standard, commonly called the 'general acceptance' test, dictates that scientific evidence is only admissible at trial if the methodology or scientific principle upon which the opinion is based is 'sufficiently' established to have gained general acceptance in the particular field in which it belongs. (p. 77)

Just exactly how courts establish "general acceptance" is unclear, but the concept does not refer to the expert's ultimate conclusion. Donaldson (2002) says:

[r]ather, the proper focus of the general acceptance test is on the underlying methodology used to generate the conclusion. If the underlying method used to generate an expert's opinion is reasonably relied upon by the experts in the field, 
the fact finder may consider the opinion-despite the novelty of the conclusion rendered by the expert. (p. 77)

A "Frye-plus-reliability" standard was articulated that required that "having determined that a technique or methodology is generally accepted, the court must still consider whether the opinion is reliable." This standard had been adopted in appeals court decisions in Illinois, e.g., Harris v. Cropmate Co. (1999). The Supreme Court said: "[a] technique is not generally accepted in the scientific community if it is by nature unreliable." The Donaldson Court was rejecting the fact that "the "Frye-plus-reliability" test impermissibly examines the data from which the opinion flows, while the technique might remain generally accepted. Questions concerning underlying data, and an expert's application of generally accepted techniques, go to the weight of the evidence, rather than its admissibility. See, e.g., People $v$. Pope (1996). In fact, the same argument, that "general acceptance implies reliability," might have been said of the other Daubert lynchpinvalidity. It is reasonable for Courts to concentrate their scarce gate-keeping resources on methods, since there is nearly an infinite variety of data to which a given method might be applied. However, when a given data source itself has been intensively studied, then its use has become a method, and scientific literature discussing it should certainly be considered. Further, as scientific knowledge evolves, generally accepted practices, e.g., bleeding a patient becomes recognized as invalid and unreliable; at what point in the transition would the courts determine that general acceptance had been withdrawn by the relevant scientific community?

Deciding about the general acceptance of a methodology is not an easy a matter. In People v. Miller (1996), the court acknowledged that "in attempting to establish such general acceptance for purposes of the case at hand, the proponent will also be asking to establish the law of the jurisdiction for future cases." (p. 204) Further,

unless the question of general acceptance has been thoroughly litigated in the previous cases, reliance on judicial practice is a hollow ritual, 2 J. Strong, McCormick on Evidence $\$ 203$, at 870 n.20 (4th ed. 1992). (p. 207)

Both the two previous quotations suggest that it could take some serious work to establish general scientific acceptance. In Duran v. Cullinan (1997), which involved extrapolating epidemiological studies, an affidavit of the expert was used. However, Donaldson contains the language that the Frye standard does not demand "unanimity, consensus, or even a majority of experts" (p. 78) to satisfy the general acceptance test-words that alone would be troubling, but are understandable in light of the previous paragraph, which pointed out that the phenomenon being studied simply had not been the subject of extensive study. The Donaldson court quotes People v. Zayas (1989): "holding that evidence of hypnotically induced recall is inadmissible under Frye because it is not generally accepted and the scientific literature is 'replete with articles imploring courts to reject such evi- 
dence because of its many flaws." (p. 85) There is clearly a major difference between the application of an accepted technique by a well respected researcher to new data and the application of marginally accepted or passé techniques to data known to be bad.

\section{Expert Reports}

While expert reports are not required under Rule 213(f)(3), most plaintiff's lawyers request them, and it is our experience that they are typically the vehicle through which most plaintiff's attorneys disclose expert opinions. Under Rule 213(f), as it is commonly called, the following must be disclosed: (i) the subject matter on which the opinion witness is expected to testify; (ii) the conclusions and opinions of the opinion witness and the bases therefore; (iii) the qualifications of the opinion witness; and (iv) any reports prepared by the witness about the case. Attorneys often merely attach the report as their answer to interrogatories, in which case the report must completely address (i)-(iii).

When the defense wishes to nominate its own economics expert, a 213(f)(3)(iv) report is often tendered, although a recent trend has seen an increasing number of defense attorneys simply responding to 213(f)(3)(i)(iii).

Discovery depositions are the general rule; bases may be elaborated upon during depositions, and occasionally additional opinions appear in response to questions.

It is not uncommon for experts to be given updated income tax or earnings data on the eve of trial, which they would use to update a previously issued report. The opposition sometimes objects that the update wasn't provided early enough. We have found no cases pursuant to the new Rule 213, but the older Rule 220(c) was litigated, and one would expect its message to continue, especially since the new Rule 213(i) adopts much of the same curious wording. The opinion in Singh v Air-Illinois at 929 said "[i]n order to prevent an undisclosed shift in theory or belief, the rule requires that a party seasonably submit a modified report or supplemental answers taking into account shifts in the expert's views." (Ill. Ann. Stat., Ch. 110A, par. 220, Committee Comments, at 440; Smith-Hurd, 1985)

The court then reviewed the two reports and concluded that the "revisions did not involve a 'shift in theory or belief.' The revised report was merely an update of the original, using the same methodology and tables to determine present cash value. Accordingly, there was no violation of Supreme Court Rule 220.” (p. 930)

Effects of Re-Marriage

In Dotson v. Sears Roebuck \& Co. (1990), relying on prior cases, this decision held that losses of consortium, which include household services, terminate upon remarriage. However, in Pfeifer v. Canyon Construction 
Company (1993), it was made clear that remarriage did not terminate a claim for financial support from a decedent spouse. The Pfeifer Court said:

The concept of consortium, as it emerges from the cases, consists primarily of intangible elements which are unique, and very personal, to any given marriage.... That relationship and those benefits cannot be duplicated. As for material services, we note first that the courts speak of a wife's 'services in the home,' services 'as [the spouse's] wife,' and 'personal services.' Too, while some material services are clearly more tangible in nature than such things as affection and companionship, they are also highly personal to, and generally flow from, the particular relationship between specific spouses. As such, they are properly part of consortium. (pp. 1029, 1030)

In Simmons v. University of Chicago Hospital and Clinics (1994), the Illinois Supreme Court noted that remarriage terminates a claim for a surviving spouse for loss of consortium. At issue in this case was a loss of consortium claim due to the death of a child. The Simmons Court found that the subsequent birth of two children to the parents' of the decedent child did not terminate the parents' loss of consortium claim with respect to the decedent child, saying:

Defendants also argue that this conclusion is contrary to the principles applicable to the analogous area of loss of consortium. Defendants note that appellate decisions have held that evidence of a subsequent remarriage is relevant in loss of spousal consortium claims and, in fact, terminates the right of a widower or widow to recover for loss of consortium. . . We disagree and note that the relationship between parent and child is different from that of husband and wife. The parent-child relationship is not replaceable and is not limited to the society of only one child. Every child is unique, and the loss of society a parent suffers upon a child's death cannot be replaced with the society of a child subsequently born. (pp. 14, 15)

\section{Divulging Income from Expert Witness Related Work}

The extent to which an expert can be forced to divulge tax records is unclear. The operative case regarding an expert's financial information is Trower $v$. Jones (1988). In this case, regarding a medical expert, the Supreme Court wrote:

We thus find that it was proper to inquire how much Dr. ----- was earning annually from services relating to rendering expert testimony, and we find no impropriety in inquiring into such income for the two years immediately preceding trial. (p. 218)

The decision went on to say: 
We also find that the circuit court properly permitted counsel to inquire, on cross-examination, as to the frequency with which Dr. ---testifies for plaintiffs. Such information clearly has some relevance in determining whether an expert witness is biased or his opinion skewed. Attorneys, judges and many trial experts themselves are well aware that certain expert witnesses appear particularly willing to testify that medical negligence has occurred, while others appear particularly inclined to testify that there was no deviation from the appropriate standard of care. Obviously, the fact that a physician testifies only for one category does not necessarily mean that his testimony is not credible. For example, a physician may adopt a policy of testifying only on behalf of other physicians in order to avoid the resentment among his colleagues which could arise from testifying on behalf of individuals suing physicians. This would not mean that he testifies on behalf of doctors who he believes were actually negligent, but only that (for personal reasons) he prefers not to testify for plaintiffs regardless of the merits of their case. A reasonable jury can be expected to recognize the possibility that the expert witness has just such a legitimate concern, and the counsel presenting the witness may even wish to point out such a possibility to the jury. Nevertheless, information as to whether a particular expert routinely testifies for a particular category of party is certainly of some value in determining whether he may have a predisposition either to exculpate or find fault. There is no sufficient reason why this information cannot be weighed and evaluated by the jury along with all of the other evidence pertaining to the credibility of an expert witness. (p. 220)

\section{It concluded with}

In summary, for the reasons herein indicated, we hold that the circuit court did not abuse its discretion in permitting defense counsel, during cross-examination of plaintiffs' expert witness, to inquire regarding (1) the annual income derived from services relating to serving as an expert witness and (2) the frequency with which the witness' testimony in prior cases had been for "people suing doctors.” (p. 222)

The phrase "relating to expert testimony" has not been litigated. An expert's Federal Rule 26 list of depositions and trial testimony would provide a basis for estimating income "derived from serving as an expert witness," and perhaps income from the underlying reports could be included. Because credible economics experts also consult on a non-disclosed basis, and that income is clearly not "derived from serving as an expert witness," there is no basis for demanding an expert's income taxes unless practically $100 \%$ of his income comes from serving as a named expert witness, in which case such taxes, or the relevant parts thereof, would appear to be fair game.

Nothing in Trower $v$. Jones requires an expert witness to disclose his total income (from consulting, expert witness income, and all other sources of income combined) or to disclose the percentage of total income earned from services related to expert witness work. If an expert witness chooses 
to answer a percentage-of-total-income question (a question he is not required to answer) and then answers the income-earned-from-expert-witness work (a question he must answer), then a simple arithmetic calculation would enable anyone to compute his total income. Therefore, an expert witness, who wishes to keep his total income confidential, should decline to answer a question on the percentage of income earned from expert witness related work.

Trower was cited in Martinez v. Pfizer (1991), which at 371 reinforced the consulting distinction by reference to the then current Rule 220(c)(5). It also cited Monier $v$. Chamberlain (1966) at 477 and cases cited therein that the discovery requests are limited to documents connected to the immediate cause of action. (Martinez v. Pfizer at 367) Requests for transcripts, testimony and affidavits in previous cases were held to run afoul of the prohibition of sub-trials of Sears v. Rutishause (1984) and Davis v. Hinde (1986).

Depositions, Disclosure, and Testimony

Opposing experts generally do not attend each others' expert depositions, but they may do so if the parties agree. At trial, there is typically a motion to bar all witnesses from the trial before they testify, and attorneys usually do not think to make an exception for their experts. In this regard, state practice differs from federal practice.

Federal Rule of Evidence 703 states that:

The facts or data in the particular case upon which an expert bases an opinion or inference may be those perceived by or made known to him at or before the hearing. If of a type reasonably relied upon by experts in the particular field in forming opinions or inferences upon the subject, the facts or data need not be admissible in evidence.

Federal Rule 705 states:

The expert may testify in terms of opinion or inference and give his reasons therefore without prior disclosure of the underlying facts or data, unless the court requires otherwise. The expert may in any event be required to disclose the underlying facts or data on cross examination.

Both were adopted in the Illinois Supreme Court case of Wilson v. Clark (1981). Rule 701 concerns opinion testimony by lay witnesses, and Rule 706 concerns court appointed experts. Rule 704, which speaks to opinion on the ultimate issue, was implicitly adopted in the decisions cited in the annuity testimony section.

An evidence deposition is required by Supreme Court Rule 212(b), if the expert witness had earlier given a discovery deposition and is unavailable. 
Hypothetical Questions

In Buford v. CHA et al (1986), the court wrote:

Generally, when an expert is asked to assume certain things as true, they must be within the realm of direct or circumstantial evidence, supportable by the facts or reasonable inferences which can be drawn there from. Smith's Transfer Corp. v. Industrial Com. (1979), 76 Ill. 2d 338 at 350. Nevertheless, expert testimony couched in terms of probabilities or possibilities based on assumed facts is not inadmissible or improper. Beloit Foundry $v$. Industrial Com. (1976), 62 Ill. 2d 535, 539; Presswood v. Morris, 70 Ill. App. 3d 513 (1979) at 517-18; Nicholas v. City of Alton (1982), 107 Ill. App. 3d 404 at 407-08. (p. 245)

Some indication of the limits for hypotheticals may be found in Carlson v. City Construction Company (1992). The appellate court rejected a second scenario developed by plaintiff's expert based on the decedent having become a civil engineer. The court noted that plaintiff's economics expert would not testify that plaintiff would have completed this degree, and found this scenario to be speculative along Christou lines. The court did rely on the first scenario testimony and the percentage range for personal consumption considered reasonable to determine the amount of remittitur it granted.

\section{Summary}

Illinois law concerning the calculation of damages in personal injury and wrongful death actions is in the mainstream of such law in the United States. It gives considerable freedom to economics experts and to the courts to determine appropriate methods of calculating economic damages. Income taxes are ignored. In wrongful death cases, the focus is on the loss to the survivors, whether calculated from the top down, with personal consumption offsets, or from the bottom up, via direct evaluation. Fringe benefits are assumed to be a part of compensation, and household services may be valued. Pre-judgment interest is not allowed, and one must discount to present value, although no specific interest rate or class of securities is mandated. Loss of capacity and loss of earnings are both recognized, but the difference is not likely to be major since the capacity must be reasonably certain to occur. Collateral sources are excluded for traditional legal reasons, except in medical malpractice cases. Not all issues of interest to a forensic economics expert have been litigated, including the indexation of pre-trial losses and the family income/decedent income choice in personal consumption offsets. 


\section{References}

Cleary, E., and M. Graham, Handbook of Illinois Evidence $\S 403.1$ at 169 , (5 ${ }^{\text {th }}$ ed.), 1990.

Illinois Pattern Instructions, Civil 2006 Edition, West Publishing, 2006.

Restatement (Second) of Torts § 908(2) (1979).

Sullivan's Law Directory, 199th Annual Edition, Volume II, Buffalo Grove, IL: Law Bulletin Publishing Company, 2005-2006.

Smith-Hurd's Illinois Compiled Statutes Annotated, West Publishing Company, St. Paul, Minnesota (1985).

\section{Citations}

22 Am. Jur. 2d Damages sec. 210 (1965)

177 Ill. 2d R. 239(a)

Adams v. Burlington Northern R.R. Co., 865 S.W.2d 748, Mo. Ct. App. (1993)

Aleckson v. Village of Round Lake Park, 176 Ill. 2d 82 (1997)

Alguire v. Walker (1987), 154 Ill. App. 3d 438, 448 (1987)

Allendorf v. Elgin, Joliet \& Eastern Ry. Co. (1956), 8 Ill. 2d 164 (1956)

Amann v. Chicago Consolidated Traction Co., 243 Ill. 263 (1909)

American National Bank v. Thompson, 158 Ill. App. 3d 478 (1987)

American National Bank and Trust Co. of Rockford, Adm'r of the Estate of Carolyn McClellan v. Robert Bourland, Adm'r of the Estat of Richard Boigenzahn, 65 Ill. App. 3d 977 (1978)

Antol v. Chavez-Pereda, 284 Ill. App. 3d 561, 572 (1996)

Arthur v. Catour, 345 Ill. App. 3d 804 (2004)

Baird v. Burlington \& Quincy RR Co., 63 Ill. 2d 408, 463 (1976)

Barry v. Owens-Corning Fiberglas Corp. 282 Ill. App. 3d 199, 203 (1996)

Beloit Foundry v. Industrial Com. (1976), 62 Ill. 2d 535 (1976)

Bernier v. Burris, 113 Ill. 2d 219 (1986)

Best v. Taylor Machine Works, 179 Ill. $2 d 267$ (1997)

Branum v. Slezak Construction Co., 289 Ill. App. 3d 948 (1997)

Brown v. Chicago \& North Western Transportation Co., 162 Ill. App. 3d 926, 936 (1987)

Buckler v. Sinclair Refining Co., 68 Ill. App. 2d 283 (1966)

Buford v. CHA et al, 131 Ill. App. 3d 235, 245 (1985)

Bullard v. Barnes, 102 Ill.2d 505 (Ill. 1984)

Caley v. Manicke (1962), 24 Ill. 2d 390, 393-394 (1962)

Carlson v. City Construction Co., 239 Ill. App. 3d 211 (1992)

Carswell v. Rosewell, 150 Ill. App. 3d 168, 171 (1986)

Chicago, Peoria and St. Louis Railroad Co. v. Woolridge, 174 Ill. 330, 335 (1898)

Christou v. Arlington Park Race Track, 104 Ill App 3d 260 (1982)

Collins v. Straka, 164 Ill. App. 3d 355, 364 (1987)

Compton v. Ubilluz et al, 353 Ill. App. 3d 863, 867 (2004)

Consolidated Coal Co. v. Haenni, 146 Ill. 614, 628 (1893)

Couch v. State Farm Insurance, 279 Ill. App. 3d 1050, 1054 (1996)

Country Mutual Insurance Co. v. Adams, 85 Ill. App. 3d 501 (1980)

Coyne v. Campbell, 11 N.Y.2d 372 (1962)

Coyne v. Campbell, 183 N.E.2d 891 (1962)

Coyne v. Campbell, 230 N.Y.S.2d 1 (1962)

Danzico v. Kelly and James Kelly, 112 Ill. App. 2d 14, 30 (1969)

Davis v. Hinde 141 Ill. App. 3d 664, 667-681 (1986) 
Devlin v. Chicago C.R. Co., 210 Ill App. 7 (1918)

Dillon v. Evanston Hospital, 199 Ill. 2d 483, 506 (2002)

Dini v. Naiditch, 20 Ill. 2d 406 (1960)

Doll v. Brown, 75 F. 3d 2100 (7th Cir.1996)

Donaldson v. Central Illinois Public Service, 199 Ill. 2d 63, 72, 81 (2002)

Dotson v. Sears Roebuck \& Co, 199 Ill. App. 3d 526 (Illinois App. 1990)

Dralle v. Ruder, 124 Ill.2d 61 (1988)

Duran v. Cullinan, 286 Ill. App. 3d 1005 (1997)

Edwards v. Atchison, Topeka and Santa Fe Railway Company, 291 Ill. App. 3d 817 (1997)

Elliott v. Willis, 92 Ill. 2d 530 (1982)

Eshelman v. Rawalt, 298 Ill. 192, 197 (1921)

Exchange National Bank of Chicago v. Air Illinois, Inc., 167 Ill. App.3d 1081, 1088 (1988)

Fetzer v. Wood, 211 Ill.App.3d 70 (1991)

Fintak v Catholic Bishop of Chicago, 9 Ill. Dec. 233 (1977)

First Midwest Trust Co. v. Rogers, 296 Ill. App. 3d 416, 431-434 (1998)

Fravel v. Morenz, 151 Ill. App. 3d 42, 46 (1986)

Freeding-Skokie Roll-Off Service, Inc. v. Hamilton, 108 Ill. 2 d 217 (1985)

Frye v. United States, 54 App. D.C. 46, 293 F.1013 (D.C. Cir.1923)

Gilman v. Kessler, 192 Ill. App. 3d 630, 633 (1989)

Gonzales v. City Wide Insulation, U.S. Dist. Lexis 6360 (1990)

Gray v. Mundelein College, 296 Ill. App. 3d 795, 799 (1998)

Grayson v. Williams, 256 F.2d 61, 65 (10th Cir. 1958)

Gulf Offshore Co. v. Mobil Oil Corp., 453 U.S. 473, 486-487 (1981)

Hall v. Chicago \& N.W. Railway Company, 5 Ill. 2d 135 (1955)

Harris v. Cropmate Co., 302 Ill. App. 3d 364 (1999)

Holton v. Memorial Hospital, 176 Ill.2d 95 (1997)

Howard v. Gulf, M. \& O. R. Co., 13 Ill App. 2d 482 (1957)

In Re Elias, 114 Ill. 2d 321, 334 (1986)

In re Estate Wernick, 127 Ill. 2d 61, 87 (1989)

Jackson v. Pellerano, 210 Ill. App. 3d 464 (1991)

Johanek et al. v. Rigsby Truck Lines, 157 Ill. App. 3d 140 (1987)

Jones \& Adams Co. v. George, 227 Ill. 64 (1907)

Karagiannakos v. Gruber, 274 Ill. App.3d 155 (1995)

Klawonn v. Mitchell, 105 Ill. 2d 458 (1985); 475 N.E.2d 857 (Ill. 1985)

Laird v. Illinois Central Gulf Railroad Company, 208 Ill. App. 3d 51 (1991)

Lake Shore and Michigan Southern Railway Co. v. Conway, 169 Ill. 505 (1897)

LaFever v. Kemlite 185 Ill. 2d 380 (1998)

LeBron v. Gottlieb. No. 06 L 12109

Leonardi v. Loyola University, 168 Ill. 2d 83, 101 (1995)

Liebig-Grigsby v. United States, U.S. Dist. (No. 00C4922), LEXIS 3682, N.D.Ill. (2003)

Liepelt v. Norfolk \& Western Ry. Co., 71 Ill. 2d 618 (1976)

Liepelt v. Norfolk \& Western Ry. Co. 62 Ill. App. 3d 653 (1978)

Long v. Friesland 178 Ill App 3d 42, 55 (1988)

Manders v. Pulice, 102 Ill. App. 2d 468 (1968)

Martinez v. Pfizer, 216 Ill. App. 3d 360 (1991)

McCann v. Lisle-Woodridge Fire Protection District, 115 Ill. App. 3d 702 (1983)

McManus v. Feist, 76 Ill. App. 2d 99 (1966)

Merchants National Bank v. Elgin, Joliet \& Eastern Ry. Co., 49 Ill. 2d 118, 122, 1971)

Monier v. Chamberlain, 66 Ill. App. 2d 472 at 477 (1966) 
Morris v Milby, 301 Ill. App. 3d 224 (1998)

Morus v. Kapusta, 339 Ill. App. 3d 483 (2003)

Nicholas v. City of Alton, 107 Ill. App. 3d 404 (1982)

Norfolk \& Western Ry. Co. v. Liepelt, 444 U.S. 490 (1980)

Olson v. Scully, 296 Ill. 418 (1921)

O'Shea v. Riverway Towing Co, 677 F.2d 1194 (7th Cir. 1982)

Patch v. Glover, 248 Ill. App. 3d 562 (1993)

Patel v. Brown Machine Co., 264 Ill. App. 3d 1039, 1061 (1994)

Peluso v. Singer General Precision, Inc., 47 Ill. App. 3d 842 (1977)

People v. Basler, 193 Ill. 2d 545, 554 (2000)

People v. Granados, 172 Ill. 2d 358, 371 (1966)

People v. Harris, 132 Ill. 2d 366, 385, (1989)

People v. Kirk, 289 Ill. App. 3d 326, 333 (1997)

People v. Miller, 173 Ill. 2d 167, 204 (1996)

People v. Pope, 284 Ill. App. 3d 695 (1996)

People v. Zayas, 131 Ill. 2d at 295 (1989)

Peterson et al. v. Lou Bachrodt Chevrolet Co. 76 Ill. 2d 353 (1979)

Petrillo v. Syntex Laboratories, 148 Ill. App. 3d 581 (1986)

Pfeifer v. Canyon Construction Company, 253 Ill.App.3d 1017 (1993)

Powers v. Illinois Central Gulf R.R. Co., 91 Ill. 2d 375 (1982)

Presswood v. Morris, 70 Ill. App. 3d 513, 517-18 (1979)

Rachel v. Consolidated Railroad Corp., 891 F. Supp. 428, 429-30 (N.D. Ohio,1995)

Richardson v. Chapman, 175 Ill. 2d 98 (1998)

Rinesmith v. Sterling, 293 Ill. App. 3d 344, 348 (1997)

Roberts v. Norfolk \& W. Ry., 229 Ill. App. 3d 206 (1992)

Robinson v. Greeley \& Hansen, 114 Ill. App. 3d 720 (1983)

Ross Co. v. Blumberg, 331 Ill App. 22, (1947)

Sears v. Rutishauser, 102 Ill. App. 2d 402, 407-408 (1984)

Shaheed v. Chicago Transit Authority, 137 Ill. App. 3d 352, 360 (1985)

Simmons v. University of Chicago Hospital and Clinics, 162 Ill. 2d 1 (1994)

Singh v Air Illinois, 165 Ill. App. 3d 923 (1988)

Smith's Transfer Corp. v. Industrial Com., 76 Ill. 2d 338 (1979)

Stevens v. Illinois Central R.R. Co., 306 Ill. 370, 377 (1922)

Stringham v. United Parcel Service, Inc., 181 Ill. App. 3d 312 (1989)

Suich v. H \& B Printing Company, Inc., 185 Ill. App. 863, 879 (1989)

Trower v. Jones, 121 Ill. 2d 211, 218-219 (1988)

Turner v. Chicago Transit Authority, 122 Ill. App. 3d 419 (1984)

Varilek v. Mitchell Engineering Co., 200 Ill. App. 3d 649, 668-672 (1990)

Voss v. Tune, 121 Ill. App. 3d 692, 693 (1984)

Wilcox v. Bierd, 330 Ill. 571 (1928)

Wilson v. Clark, 84 Ill. 2d 186 (1981)

Williams v. Board of Education, 52 Ill. App. 3d 328 (1977)

Wood et al. v. Mobil Chemical Company 50 Ill. App. 3d 465 (1977)

Zavala v. Powermatic, Inc., 167 Ill. 2d 542, 546 (1995) 


\section{Appendix -- Jury Instructions}

The Illinois Supreme Court approves pattern jury instructions for use in Illinois trials. The Civil 2006 Edition, published by West Publishing, will be referred to here; earlier editions were the 2005 Edition, the $2000 \mathrm{Edi}$ tion, the 1997 Edition, the Fourth Edition (1995), the Third Edition (1992), the Second Edition (1971) and the First Edition (1961) Pattern jury instructions are called Illinois Pattern Instructions, abbreviated IPI. The Illinois Supreme Court Committee on Jury Instructions states that instructions are to be "conversational, understandable, unslanted and accurate," in the words of the forward to the 1971 edition. Supreme Court Rule 177 Ill. 2 d R. 239(a) directs the trial court to use IPI instructions where applicable:

Use of IPI Instruction; Requirements of Other Instructions. Whenever Illinois Pattern Jury Instructions (IPI) contain an instruction applicable in a civil case, giving due consideration to the facts and the prevailing law, and the court determines that the jury should be instructed on the subject, the IPI instruction shall be used, unless the court determines that it does not accurately state the law.

However, the Illinois Supreme Court has observed that IPI instructions are not exempt from challenge. (Powers v. Illinois Central Gulf R.R. Co., 1982) Thus, when an instruction on a point exists, it is to be given, unless the trial judge determines that it is inconsistent with current law. Where no Illinois pattern jury instruction accurately states the law, a non-IPI instruction is permissible under Supreme Court Rule 239(a) (134 Ill. 2d R. 239(a)) if it is simple, brief, impartial, and non-argumentative. (Fravel v. Morenz, 1986) Because "Notes on Use" and "Comments" often provide relevant law and interpretation, we have thus given a high priority to an exact listing of the jury instructions.

The reader will note gaps in the IPI numbering. These are not mistakes; rather they indicate the desire for continuity of the numbers across editions of the IPI while reflecting the changing nature of the law, e.g., 30.02 on "the nature, extent and duration of the injury" has been withdrawn since Powers v. Illinois Cent. Gulf R. R. Co. ruled that, while the jury could consider these, they did not constitute a separate element of damages.

Below we quote the Illinois Pattern Jury Instructions on Damages (instruction numbers beginning with 30), Wrongful Death (instructions beginning with 31), Injury to Spouse and Family Members (instructions beginning with 32), Mitigation (instruction 33), Future Damages (instructions 34), and Punitive Damages (instructions beginning with 35$)^{12}$

\footnotetext{
${ }^{12}$ Punitive damages instructions are included because such forensic economics testimony in Illinois is allowed in torts cases under certain conditions, although this occurs in only a small number of cases. The conditions under which this occurs are mentioned later in the paper.
} 
DAMAGE INSTRUCTIONS-In this section any appropriate damages are inserted between the two paragraphs in IPI 30.01 below.

30.01 Measure of Damages—Personal and Property

If you decide for the plaintiff on the question of liability, you must then fix the amount of money which will reasonably and fairly compensate him for any of the following elements of damages proved by the evidence to have resulted from the [negligence] [wrongful conduct] [of the defendant], [taking into consideration (the nature, extent and duration of the injury) (and) (the aggravation of any pre-existing ailment or condition)].

Here insert the elements of damages which have a basis in the evidence]

Whether any of these elements of damages has been proved by the evidence is for you to determine.

30.04 Measure of Damages-Disfigurement

The disfigurement resulting from the injury.

30.04.01 Measure of Damages—Disability/Loss of a Normal Life

[The disability experienced (and reasonably certain to be experienced in the future)]

[Loss of a normal life experienced (and reasonably certain to be experienced in the future)]

30.04.02 Loss of a Normal Life-Definition

When I use the expression "loss of a normal life", I mean the temporary or permanent diminished ability to enjoy life. This includes a person's inability to pursue the pleasurable aspects of life.

30.04.03 Increased Risk of Harm-Measure of Damages

The increased risk of future [ specific condition] [harm] resulting from the [injury] [injuries] [condition] [conditions].

30.04.04 Increased Risk of Harm-Calculation

To compute damages for increased risk of future specific condition [harm] only, you must multiply the total compensation to which the plaintiff would be entitled if specific condition were certain to occur by the proven probability that specific condition will in fact occur.

[You do not reduce future damages by this formula if those damages are more [likely than not] [probably true than not true] to occur.]

30.05 Measure of Damages-Pain and Suffering-Past and Future

The pain and suffering experienced [and reasonably certain to be experienced in the future] as a result of the injuries.

30.05.01 Measure of Damages-Emotional Distress-Past and Future

The emotional distress experienced [and reasonably certain to be experienced in the future].

30.06 Measure of Damages-Medical Expense-Past and Future-Adult Plaintiff, Emancipated Minor, or Minor Whose Parent Has Assigned Claim to Minor 
The reasonable expense of necessary medical care, treatment, and services received [and the present cash value of the reasonable expenses of medical care, treatment and services reasonably certain to be received in the future].

30.07 Measure of Damages_Loss of Earnings or Profits-Past and FutureAdult Plaintiff, Emancipated Minor, or Minor Whose Parent Has Assigned Claim to Minor

[The value of (time) (earnings) (profits) (salaries) (benefits) lost] [.] [and] $[(\mathrm{T})$ he present cash value of the (time) (earnings) profits) (salaries) (benefits) reasonably certain to be lost in the future].

30.08 Measure of Damages-Loss of Future Earnings-Future Medical Expenses-Minor Plaintiff

The present cash value of (time) (earnings) (profits) (salaries) (benefits) [(medical) care, treatment, and services] (caretaking expense) reasonably certain to be lost (or incurred) in the future after the plaintiff has reached the age of eighteen.

30.09 Measure of Damages-Caretaking Expense-Past and Future-Adult Plaintiff, Emancipated Minor, or Minor Whose Parent Has Assigned Claim to Minor

The reasonable expense of necessary help which has been required as a result of his injury [and the present cash value of such expense reasonably certain to be required in the future].

30.21 Measure of Damages-Personal Injury-Aggravation of Pre-Existing Condition-No Limitations

If you decide for the plaintiff on the question of liability, you may not deny or limit the plaintiff's right to damages resulting from this occurrence because any injury resulted from [an aggravation of a pre-existing condition] [or] [a preexisting condition which rendered the plaintiff more susceptible to injury].

\subsection{Collateral Source-Damages}

If you find for the plaintiff you shall not speculate about or consider any possible sources of benefits the plaintiff may have received or might receive. After you have returned your verdict the court will make whatever adjustments are necessary in this regard.

\subsection{Injury from Subsequent Treatment}

If [a defendant] [defendants] negligently cause[s] [injury to] [a condition of] the plaintiff, then the defendant[s] [is] [are] liable not only for the plaintiff's damages resulting from that [injury] [or] [condition], but [is] [are] also liable for any damages sustained by the plaintiff arising from the efforts of health care providers to treat the [injury] [or] [condition] caused by the defendant[s] [even if (that) (those) health care provider(s) (was) (were) negligent.]

WRONGFUL DEATH-In this section we only quote the IPI for the death of an adult with a spouse or lineal next of kin surviving (e.g., a son or daughter $)^{13}$ This section also contains IPI for survival actions.

${ }^{13}$ Additional IPI for deceased minor child with a surviving lineal next of kin, collateral next of kin of a deceased child, lineal and collateral next of kin of a deceased child, and similar instructions in the case of an adult decedent with collateral next of kin can be found at 
31.04 Measure of Damages—Wrongful Death—Adult Decedent—Widow and/or Lineal Next of Kin Surviving

If you decide for the plaintiff on the question of liability, you must then fix the amount of money which will reasonably and fairly compensate the widow and/or lineal next of kin, e.g. son. of the decedent for the pecuniary loss proved by the evidence to have resulted to widow and/or lineal next of kin, e.g., son from the death of the decedent. "Pecuniary loss" may include loss of money, benefits, goods, services, [and] society [and sexual relations].

Where a decedent leaves widow and/or lineal next of kin, e.g., son, the law recognizes a presumption that widow and/or lineal next of kin, e.g. son has sustained some substantial pecuniary loss by reason of the death. The weight to be given this presumption is for you to decide from the evidence in this case.

In determining pecuniary loss, you may consider what the evidence shows concerning the following:

[1. What (money,) (benefits,) (goods,) (and) (services) the decedent customarily contributed in the past; ]

[2. What (money,) (benefits,) (goods,) (and) (services) the decedent was likely to have contributed in the future; ]

[3. Decedent's personal expenses (and other deductions); ]

[4. What instruction, moral training, and superintendence of education the decedent might reasonably have been expected to give his child had he lived;]

[5. His age;

[6. His sex;]

[7. His health;]

[8. His habits of (industry,) (sobriety,) (and) (thrift);]

[9. His occupational abilities; ]

[10. The marital relationship that existed between widow and decedent ;]

[11. The relationship between _lineal next of kin, e.g. son and decedent.] [ Widow is not entitled to damages for loss of decedent's society and sexual relations after date of widow's remarriage.]

31.07 Measure of Damages—Wrongful Death—Factors Excluded

[Under Count sider the following:

[1. The pain and suffering of the decedent;

[2. The grief or sorrow of the (widow) (and) (next of kin); [or]

[3. The poverty or wealth of the (widow) (and) (next of kin)]

31.08 Damages—Wrongful Death—Contributory Negligence-More Than One Beneficiary

If you find that [ surviving spouse ] [or] [ next of kin ] negligently contributed to cause the death of the decedent, the negligence of that person does not bar recovery by the plaintiff, but in any award you make you may not include damages for any pecuniary injuries suffered by that person.

http://fac.comtech.depaul.edu/jciecka/IPIChild.doc or http://www.legaleconometrics.com. The main differences in these instructions center on the presumption of loss. In the case of a spouse or lineal next of kin there is a presumption of substantial pecuniary loss and the jury must decide the weight to be given to this presumption. There is no such presumption in the case of collateral next of kin. 
31.08.01 Damages—Wrongful Death—Contributory Negligence—One Beneficiary

If you find that name of beneficiary negligently contributed to cause the death of the decedent, then you must return a verdict in favor of the defendant.

31.09 Action for Wrongful Death and Survival Action Brought By Personal Representative

The plaintiff administrator's or executor's name brings this action in a representative capacity by reason of his being [administrator] [executor] of the estate of deceased's name, deceased. He represents names of widow and/or next of kin, the [widow] [and] [next of kin] of the deceased [, and the estate of the deceased]. They are the real parties in interest in this lawsuit, and in that sense are the real plaintiffs whose damages you are to determine if you decide for the [administrator] [executor] of the estate of deceased's name.

\subsection{Damages-Survival Action}

If you decide for the plaintiff on the question of liability, you must then fix the amount of money which will reasonably and fairly compensate the estate for any of the following elements of damages proved by the evidence to have resulted from the [negligence] [wrongful conduct] of the defendant during the period between the time of the decedent's injuries and the time of his death, taking into consideration the nature, extent, and duration of the injury:

[Here insert the elements of damages which have a basis in the evidence.]

Whether any of these elements of damages has been proved by the evidence is for you to determine.

31.11 Damages—Loss of Society—Definition

When I use the term "society" in these instructions, I mean the mutual benefits that each family member receives from the other's continued existence, including love, affection, care, attention, companionship, comfort, guidance, and protection.

\subsection{Wrongful Death Case-Discount of Future Damages}

If you find for the plaintiff, then in assessing damages you may consider how long the names of widow and/or next of kin will be likely to sustain pecuniary losses as a result of decedent's name's death, considering how long decedent's name was likely to have lived and how long lineal next of kin, e.g., parent [is] [are] likely to live.

In calculating the amount of these pecuniary losses consisting of money, benefits, goods or services, you must determine their present cash value. "Present cash value" means the sum of money needed now which, together with what that sum may reasonably be expected to earn in the future, will equal the amounts of those pecuniary losses at the times in the future when they will be sustained.

Damages for [loss of sexual relations] [loss of society] are not reduced to present cash value.

31.13 Mortality Tables as Evidence of Damages-Wrongful Death Case

If you find for the plaintiff, then in assessing damages you may consider how long the names of widow and/or next of kin will be likely to sustain pecuniary losses as a result of decedent's name's death, considering how long decedent's name was likely to have lived and how long names of widow and/or next of kin to live [is] [are] likely to live. 
According to a table of mortality in evidence, the life expectancy of a [male] person aged years is__ years. That of a [female] person aged years is __ years [and that of a (male) person aged __ years is __years]. These figures are not conclusive. They are the average life expectancies of persons who have reached those ages. They may be considered by you in connection with other evidence relating to the probable life expectancies of the decedent and [his widow] [and] [his next of kin] including evidence of the decedent's occupation, health, habits and activities, bearing in mind that some persons live longer and some persons live less than the average.

In calculating the amount of these pecuniary losses consisting of money, benefits, goods or services, you must determine their present cash value. "Present cash value" means the sum of money needed now which, together with what that sum may reasonably be expected to earn in the future, will equal the amounts of those pecuniary losses at the times in the future when they will be sustained.

Damages for [loss of sexual relations] [loss of society] are not reduced to present cash value.

INJURY TO SPOUSE AND FAMILY MEMBERS -- In this section any appropriate damages are inserted between the two paragraphs in IPI 32.01 below.

32.01 Measure of Damages-Injury to Spouse or Family Member

If you decide for the plaintiff on the question of liability, you must then fix the amount of money which will reasonably and fairly compensate him for any of the following elements of damages arising out of injuries to [his wife] [his child] [his parent] proved by the evidence to have resulted from the [negligence] [wrongful conduct] [of the defendant].

\section{[Here insert the elements of damage which have a basis in the evidence.]}

Whether any of these elements of damages has been proved by the evidence is for you to determine.

32.02 Measure of Damages-Injury to Spouse-Medical Expense-Past and Future

The reasonable expense of necessary medical care, treatment and services received by his wife [and the present cash value of the reasonable expense of necessary medical care, treatment and services reasonably certain to be received in the future.]

32.03 Measure of Damages—Injury to Spouse-Loss of Services-Past and Future

The reasonable value of the services of his wife of which he has been deprived [and the present cash value of the services of his wife of which he is reasonably certain to be deprived in the future].

32.04 Measure of Damages-Injury to Spouse-Loss of Consortium

The reasonable value of the society, companionship and sexual relationship with his wife of which he has been deprived [and the society, companionship and sexual relationship with his wife of which he is reasonably certain to be deprived in the future]. 
32.05 Measure of Damages-Injury to a Child-Medical Expenses-Past and Future

The reasonable expense of necessary medical care, treatment and services received by the child [and the present cash value of the reasonable expenses of necessary medical care, treatment and services reasonably certain to be received in the future until the child reaches age 18.]

32.06 Measure of Damages—Loss of Services of Child-Past and Future

The reasonable value of the services of the minor child of which the parent has been deprived [and the present cash value of the services of the minor child of which the parent is reasonably certain to be deprived in the future until the child reaches age 18.]

\section{DAMAGES-MITIGATION}

33.01 Mitigation of Damages—Personal Injury

In fixing the amount of money which will reasonably and fairly compensate the plaintiff, you are to consider that an injured person must exercise ordinary care to obtain medical treatment. Damages proximately caused by a failure to exercise such care cannot be recovered.

\section{DAMAGES-FUTURE DAMAGES-LENGTH OF TIME DAMAGES WILL CONTINUE-DISCOUNT OF DAMAGES-MORTALITY TABLES}

34.01 Damages Arising in the Future-Extent and Amount

If you find that [a] [the] plaintiff is entitled to damages arising in the future [because of injuries] [or] [because of future (medical) (caretaking) expenses] [or] [because of loss of earnings] [or] [loss of the services of name of minor child ] [or] [because of (loss of society) (or) (loss of companionship and sexual relations) ], you must determine the amount of these damages which will arise in the future.

[If these damages are of a continuing nature, you may consider how long they will continue.] [If these damages are permanent in nature, then in computing these damages you may consider how long the plaintiff (and his spouse) (is) (are) likely to live.]

[With respect to a loss of future earnings, you may consider that some persons work all their lives and others do not; that a person's earnings may remain the same or may increase or decrease in the future.]

34.02 Damages Arising in the Future-Discount to Present Cash Value

In computing the damages arising in the future [because of future (medical) (caretaking) expenses] [or] [because of the loss of (future earnings) (benefits) (or) (services)] you must determine their present cash value. "Present cash value" means the sum of money needed now, which, when added to what that sum may reasonably be expected to earn in the future, will equal the amount of the [expenses] [and] [earnings] [benefits] at the time in the future when [the expenses must be paid] [or] [the earnings (benefits) would have been received].

Damages for [pain and suffering] [disability] [loss of a normal life] [and] [disfigurement] [loss of (society) (companionship) (and) (sexual relations)] are not reduced to present cash value. 
34.04 Damages Arising in the Future-Mortality Tables as Evidence of Damages-Injury Case

According to a table of mortality in evidence, the life expectancy of a person aged ___ years is ___ years. This figure is not conclusive. It is the average life expectancy of persons who have reached the age of _. It may be considered by you in connection with other evidence relating to the probable life expectancy of the plaintiff in this case, including evidence of his occupation, health, habits, and other activities, bearing in mind that some persons live longer and some persons less than the average.

\section{PUNITIVE DAMAGES}

35.01 Punitive/Exemplary Damages—Willful and Wanton Conduct

If you find that the defendant's conduct was willful and wanton and proximately caused injury to the plaintiff, and if you believe that justice and the public good require it, you may, in addition to any other damages to which you find the plaintiff entitled, award an amount which will serve to punish the defendant and to deter the defendant and others from similar conduct.

35.02 Punitive/Exemplary Damages—Willful and Wanton Conduct-Corporate Defendant's Liability Based on Tort of Employee

The defendant name of corporate defendant is a corporation and can act only through its officers and employees. As to plaintiff's claim for compensatory damages against name of corporate defendant, any act or omission of an officer or employee within the scope of his employment is the action or omission of the defendant name of corporate defendant.

As to plaintiff's claim for punitive damages against name of corporate defendant, a different rule applies. Punitive damages may be awarded against name of corporate defendant only (1) if you find in favor of the plaintiff and against name of corporate defendant under Count _ of the complaint, and (2) if you find that, as to the act(s) or omission(s) giving rise to liability under Count _, [ state condition (a), (b), (c), or (d) ] [one or (more) (both) of the following conditions (is) (are) proved:]

[ (a) ] [The corporation, through its management, authorized the doing and the manner of the act or omission] [; or]

[ (b) ] [The employee responsible for the act or omission was unfit, and the corporation was reckless in employing him] [; or]

[ (c) ] [The act or omission was that of a managerial employee who was acting in the scope of his employment] [; or]

[(d)] [The corporation, through its management or a managerial employee, ratified or approved the act or omission].

If you find for the plaintiff and against the defendant under Count _ of the complaint, and if you further find that restate condition (a). (b). (c), or (d) [one or (more) (both) of these conditions (is) (are) proved], and if you further believe that justice and the public good require it, you may, in addition to any other damages to which you find the plaintiff entitled, award an amount which will serve to punish name of corporate defendant and to deter name of corporate defendant and others from similar conduct. 